IZA DP No. 9242

The Power of (Non) Positive Thinking:

Self-Employed Pessimists Earn More than Optimists

Christopher Dawson

David de Meza

Andrew Henley

G. Reza Arabsheibani

July 2015 


\title{
The Power of (Non) Positive Thinking: Self-Employed Pessimists Earn More than Optimists
}

\author{
Christopher Dawson \\ University of Bath \\ David de Meza \\ London School of Economics \\ Andrew Henley \\ Aberystwyth University and IZA
}

G. Reza Arabsheibani

London School of Economics and IZA

Discussion Paper No. 9242

July 2015

IZA

P.O. Box 7240

53072 Bonn

Germany

Phone: +49-228-3894-0

Fax: +49-228-3894-180

E-mail: iza@iza.org

Any opinions expressed here are those of the author(s) and not those of IZA. Research published in this series may include views on policy, but the institute itself takes no institutional policy positions. The IZA research network is committed to the IZA Guiding Principles of Research Integrity.

The Institute for the Study of Labor (IZA) in Bonn is a local and virtual international research center and a place of communication between science, politics and business. IZA is an independent nonprofit organization supported by Deutsche Post Foundation. The center is associated with the University of Bonn and offers a stimulating research environment through its international network, workshops and conferences, data service, project support, research visits and doctoral program. IZA engages in (i) original and internationally competitive research in all fields of labor economics, (ii) development of policy concepts, and (iii) dissemination of research results and concepts to the interested public.

IZA Discussion Papers often represent preliminary work and are circulated to encourage discussion. Citation of such a paper should account for its provisional character. A revised version may be available directly from the author. 


\section{ABSTRACT \\ The Power of (Non) Positive Thinking: Self-Employed Pessimists Earn More than Optimists*}

Developing further the accumulating evidence that self-employment attracts optimists, this paper investigates the relationship between earnings and prior optimism. It finds that selfemployed optimists earn less than self-employed realists. Amongst employees, optimists earn more. These results are consistent with biased expectations leading to entry errors. As a test of validity, we find that amongst the married, future divorcees have higher financial expectations but their realisations are no worse, suggesting our optimism measure captures an intrinsic psychological trait associated with rash decisions.

JEL Classification: D84, M13

Keywords: financial optimism, expectations, self-employment

Corresponding author:

Andrew Henley

School of Management and Business

Aberystwyth University

Llanbadarn

Aberystwyth, SY23 3AL

United Kingdom

E-mail: a.g.henley@aber.ac.uk

\footnotetext{
${ }^{*}$ We are grateful to Thomas Åstebro, Hans Hvide, Ross Levine, Yona Rubinstein and participants in the $5^{\text {th }}$ HEC Entrepreneurship Workshop for their very helpful comments.
} 
"What wild imaginations one forms where dear self is concerned! How sure to be mistaken!" Jane Austen

"The first principle is that you must not fool yourself and you are the easiest person to fool." Richard P. Feynman

\section{Introduction}

Self-employment tends to attract optimists, as various studies find. ${ }^{1}$ Optimists downplay the possibility of unfavourable events occurring, and their self-belief leads them to think they can cope should they arise. Overestimating returns in self-employment does not of itself imply selection on optimism. Optimists will also overestimate their returns in paid employment, so their occupational choice may not be affected. Nevertheless, the uncertainty surrounding business start-ups and the sense of self-determination generated imply the scope to exaggerate prospects is greatest in self-employment. Along these lines, Dawson et al. (2014) find that optimism, measured as financial forecast error, increases on becoming selfemployed.

There is also evidence that the economic return to self-employment is low. According to Hamilton (2000), the median self-employed worker earns less than they would in selfemployment. Similarly, Moskowitz and Vissing-Jorgenson (2002) find that the return on the equity invested in private businesses is not high enough to compensate for the risk involved. Willingness to accept lower returns may be the result of non-pecuniary benefits of selfemployment such as autonomy. Tax evasion and avoidance opportunities may also reduce reported or actual earnings. There is an option value in becoming self-employed so rational experimentation could also account for low earnings. This paper looks at the role of

\footnotetext{
${ }^{1}$ For example Arabsheibani et al. (2000), Cassar (2010), Puri and Robinson (2013) and Dawson et al. (2014).
} 
optimism. If entrants overestimate the returns to self-employment, they will tend to start businesses with low expected returns, objectively evaluated. ${ }^{2}$

In outline, our methodology is as follows. Errors in forecasting earnings in prior salaried employment are correlated with subsequent self-employment earnings, controlling for observables and past wages. Earnings in self-employment are declining in optimism, a pattern that cannot be generated by temporary or permanent income shocks experienced as an employee.

The selection effect of optimism evidently does not apply to those who never enter self-employment. For this group, the relation between past optimism and future earnings should be different. If expectations are rational, optimism measured as financial forecast error, is the consequence of unlucky income realisations. Amongst individuals with the same earnings history, it is, therefore, those with the highest forecast, the optimists, who have the greatest underlying earning power. Prior optimism is therefore positively correlated with subsequent earnings. In practice, measured optimists comprise both the unlucky and the biased. For employees, only the former effect impinges on earnings while for the selfemployed, both effects potentially apply. In our data, the earnings of employees are increasing in measured optimism, while those of the self-employed are decreasing, indicating the importance of selection effects. ${ }^{3}$

The two papers closest to ours are Hvide and Panos (2013) and Hamilton, Papageorge and Pande (2014). Both look at how aspects of preferences affect entry into self-employment

\footnotetext{
${ }^{2}$ The reasoning is that of de Meza and Southey (1996) and Camerer and Lovello (1999) and in essence the same argument as applied by Malmendier and Tate (2008) to explain why optimistic CEOs are more likely to make value-destroying acquisitions. Astebro (2010) finds the returns to independent inventors are below those of equally risky investments but cannot directly link this to optimism. It is possible but implausible that selection effects may increase earnings. For it may draw in more risk-averse types with higher yielding opportunities.

${ }^{3}$ Intrinsic optimism may have real effects, such as influencing the boss to pay more, but these effects will already be present in prior employee earnings, controlling for which eliminates the effect.
} 
and subsequent earnings. In Hvide and Panos, the taste parameter is risk preference, proxied by stock market participation and personal leverage. According to the reduced form estimates, risk tolerance encourages entry but depresses earnings. The interpretation is that more risk tolerant types accept lower expected return projects, a selection effect. Hamilton, Papageorge and Pande study the effect of the "big five" personality traits. Personality potentially affects relative earning power in paid and self-employment as well as relative non-pecuniary attraction. To identify these selection and treatment effects, a structural model

is estimated using simulated maximum likelihood. Openness to new experience is found to make self-employment more attractive but lowers its expected financial returns. According to the model, the sign of selection and treatment effects on earnings is the same. Both of these papers involve rational expectations. In our case, it is the effects of forecast bias that are measured, and therefore results have welfare implications.

The next section sets out the analytical issues. Section 3 describes the data and discusses the implementation of the method. Results follow in Section 4. As a test of the robustness of the optimism effect on project selection, Section 5 shows optimists are more likely to divorce. Finally, brief conclusions are drawn.

\section{Past Optimism and Future Earnings: Theory}

Optimism, in this paper is measured as financial forecast error. This has the advantage of directly concerning the relevant bias, but as earnings are a component of optimism, care must be taken to ensure that any relationship is not purely mechanical. Measured optimism may arise for two reasons. Optimism due to unlucky income realisations will be associated with higher future earnings if the shock is transitory or no change if the shock is permanent. Forecast error may also be due to systematic bias, as a large psychological literature suggests 
(Weinstein, 1980). If setting up a business gives more scope for optimism than continuing as an employee, then, as proposed by de Meza and Southey (1996), optimists tend to opt into self-employment. Evidence that the self-employed are more optimistic than employees is provided by, inter alia, Arabsheibani et al. (2001), Puri and Robinson (2007, 2013) Åstebro, Jeffrey, and Adomdza (2007). Dawson et al. (2014) show that optimism predates selfemployment but is increased by self-employment. If optimistic self-selection occurs, a further implication is that self-employed optimists will tend to earn less than self-employed pessimists, controlling for earnings in paid-employment.

This section presents the simplest model that provides a basis for the empirical work. Begin by assuming that everyone in the workforce starts as an employee. At the end of each period they are presented with a selection of self-employment opportunities and either take the most attractive or remain in their current job. Once this decision is taken, they forecast their next period income. Individual $i$ 's forecast at $t-1$ of their income at $t$ is

$$
\text { forecast }_{i t}=\text { rational expectation }_{i t}+O_{i}
$$

where $O_{i}$ is intrinsic optimism, a psychological tendency to over estimate expected returns. This propensity is initially assumed uncorrelated with true earning power. There is heterogeneous bias, but forecasts are nevertheless grounded on rational expectations. Those with the highest forecasts tend to have the highest rational expectation and so do best.

$$
\begin{aligned}
& \text { Realised earnings are } \\
& \qquad \text { earnings }_{i t}=\text { rational expectation }_{i t}+\varepsilon_{i t}+p_{i t}
\end{aligned}
$$

where $\varepsilon_{i t}$ is a transitory income shock and $p_{i t}$ is a permanent shock. Measured optimism, as distinct from intrinsic optimism, is

$$
\text { measuredoptimism }_{i t}=\text { forecast }_{i t}-\text { earnings }_{i t}=O_{i}-\varepsilon_{i t}-p_{i t}
$$


From (1), (2) and (3) and assuming that rationally expected earnings only differ in each period by the shock to permanent income,

$$
\begin{aligned}
\text { earnings }_{i t}= & \text { rational expectation } \\
\text { it }-1 & +\varepsilon_{i t}+p_{i t}+p_{i t-1} \\
& =\text { earning }_{i t-1}+\text { measuredoptimism }_{i t-1}-O_{i}+\varepsilon_{i t}+p_{i t}
\end{aligned}
$$

The wage equation (4) is the basis for empirical estimation. Realised earnings are observable, as is measured optimism. Intrinsic optimism is not observable, but as it is a component of measured optimism with opposite sign to its direct appearance in the equation, its magnitude has no influence on earnings. The same is true of permanent shocks. ${ }^{4}$ However, past optimism is decreasing in lagged transitory shocks, which do not otherwise appear in (4). The first proposition is thus:

\section{For employees, future earnings are increasing in past measured optimism.}

Consider next those moving into self-employed in period $t$. For simplicity ignore nonpecuniary aspects of occupational choice, so entry occurs if subjectively estimated expected earnings in the best available prospect exceed the expected wage. This requires,

$$
\text { prospect rational expectation }_{i t}>\text { rational expectation }_{i t-1}+O_{i}(1-g)
$$

where $g>1$ reflects the greater opportunities for optimism to inflate prospective selfemployment earnings than employee earnings. The higher is intrinsic optimism, the lower is the entry threshold into self-employment, implying the mean premium on acceptable opportunities is decreasing in optimism, say $\left(\alpha-z O_{i}\right)$, where $\alpha, z>0$. It follows that selfemployed earnings $s_{i t}$

$$
=\left(\alpha-{ }_{z} O_{i}\right)+\text { rational expectation }{ }_{i t-1}+p_{i t-1}+p_{i t}+e_{i t}
$$

As measuredoptimism it $-1_{1}=O_{i}-\varepsilon_{i t-1}-p_{i t-1}$,

\footnotetext{
${ }^{4}$ As in Gervais and O'Dean (2001), it may take time to adjust to a negative permanent shock during which time optimism prevails.
} 
selfemployed earnings $s_{i t}$

$$
\begin{aligned}
& =\left(\alpha-z O_{i}\right)+\text { employeeearning }_{i t-1}-O_{i} \\
& + \text { measuredoptimism }_{i t-1}+p_{i t}+\epsilon_{i t}
\end{aligned}
$$

where $\epsilon_{i t}$ is an error term reflecting that realised earnings in self-employment will differ from expected earnings. For the self-employed, higher intrinsic optimism is associated with lower earnings because of the addition of the first term on the RHS of (7). ${ }^{5}$ A permanent income shock to employee earnings affects lagged earnings and optimism in exactly offsetting ways in (7). Such shocks may lead to entry into self-employment but cannot explain the relation between past optimism and earnings within self-employment. To the extent that higher measured optimism when an employee is due to intrinsic psychology, it is associated with lower self-employment earnings. If measured optimism is attributable to transitory random income shocks, it will be accompanied by higher selfemployment earnings. Employee optimism resulting from permanent income shocks is uncorrelated with self-employment earnings.

From (4) and (7), higher prior optimism depresses the earnings of the self-employed more than of employees. If the entry effect is sufficiently large, it may be that in selfemployment optimism has a negative effect on earnings. ${ }^{6}$

The analysis has so far assumed that intrinsic optimism does not have a direct performance effect on earnings. This is not obvious. For example, as noted by Trivers (2000), optimism may have evolved positively to influence others. The best way to convince others of your competence is really to believe it yourself. For paid employment, the target is most

\footnotetext{
${ }^{5}$ Hvide (2002) assumes optimism evolves to secure bargaining advantages and Brunnermeier and Parker (2005) assume individuals choose to be optimistic to savour the anticipation of success even if success is thereby made less likely. Neither explanation directly accounts for heterogeneity of beliefs.

${ }^{6}$ If prior optimism is measured over a number of periods and there is some learning, then controlling for performance permanent shocks imply lower expectations creating a tendency for a positive association between optimism and subsequent earnings.
} 
obviously the boss, but could include customers or suppliers. On this view, intrinsic optimists really do perform better. The rational expectation is therefore increasing in intrinsic optimism. There is a potential paradox here. If a high forecast is fully self-fulfilling, it is not optimistic in our sense. The approach taken here is that individuals are biased relative to the real effects attributable to their bias. Past evidence of how well an individual did is the basis for future expectations, even if these realisations are themselves influenced by optimism. For those remaining in paid-employment, the forecast is therefore still given by (1), so (4) is unchanged. In self-employment, there is no boss to lobby for a pay rise and the owner is likely responsible for more key operating decisions for which an unbiased evaluation of alternatives is the best approach. As well as entering business ownership inappropriately, optimists are then worse at running their businesses. The mean return of objectively acceptable projects, $\alpha$, is thus decreasing in optimism. If those switching into selfemployment do not realise this performance effect, they will overestimate expected returns from entry by even more, implying a higher $z$. The form of (7) is unchanged, but unrecognised performance effects of optimism will augment its negative effect on earnings.

It is possible to make some headway in teasing out the selection channel. The reason is that the effect of selection on entry opportunity disappears when optimism takes extreme values. Therefore, if optimism still has a negative effect on self-employment earnings at these values, it must be due to an operating effect.

Consider a collection of individuals differing only in their intrinsic optimism. Each is presented with a random self-employment opportunity, accepting it if its expected income is believed to exceed a common threshold. More optimistic individuals are willing to accept 
objectively worse opportunities. As a function of intrinsic optimism, $O$, expected selfemployment earnings are;

$$
\bar{s}(O)=\frac{\int_{s^{*}}^{s^{h}} f(s) s d s}{\int_{s^{*}}^{s^{h}} f(s) d s}
$$

where $f(s)$ is the density of the distribution of the expected earnings of self-employment opportunities, objectively evaluated, with upper support $s^{h}$. The expected earnings cut off is $s^{*}(O), s^{* \prime}(O)<0$

$$
\frac{d \bar{s}}{d O}=\frac{f\left(s^{*}\right)}{\int_{s^{*}}^{s^{h}} f(s) d s}\left[\frac{\int_{s^{*}}^{s^{h}} f(s) s d s}{\int_{s^{*}}^{s^{h}} f(s) d s}-s^{*}\right] s^{* \prime}(O) \leq 0
$$

The signing follows as the first term in the square brackets, average earnings of acceptable projects, is a weighted sum of terms greater than $s^{*}$.

The selection effects of optimism on earnings vary according to where measured. Consider the most extreme optimists. Their acceptance threshold is low. As $s$ falls to the lower support, the square bracketed term in (8) tends to a finite value, the mean of $s$ less the lower support. If the pdf of $s$ tends to zero as the lower support is approached, the first term multiplying the square bracket therefore tends to zero. Thus the selection effect of optimism disappears for extreme optimists.

At the other end of the scale, hardly any projects are acceptable, so the first term in the square brackets of (8) tends to $s^{*}$ as optimism falls. It is though multiplied by a term that tends to infinity as $s^{h}$ is approached. There is no definite conclusion concerning whether selection effects weaken at extreme pessimism. Table 1 shows a discrete example where selection effects are weaker for the more extreme pessimists. 
Table 1: Extreme pessimism and selection

\begin{tabular}{|c|c|c|c|c|c|c|c|}
\hline$s^{*}$ & 10 & 9 & 8 & 7 & 6 & 5 & 4 \\
\hline Entry & 1 & 2 & 5 & 10 & 15 & 18 & 19 \\
\hline $\bar{S}$ & 10 & 9.5 & 8.6 & 7.8 & 7.2 & 6.83 & 6.65 \\
\hline$\Delta \bar{S} / \Delta s$ & & 0.5 & 0.9 & 0.8 & 0.6 & 0.39 & 0.18 \\
\hline
\end{tabular}

Extreme measured optimism must involve extreme intrinsic optimism and at these points the slope of self-employed earnings will be driven by transitory shocks.

The effects of selection on entry opportunity only apply when optimism is close to its highest level and probably also when optimism is close to its lowest level. So at extremes of optimism self-employment income will be increasing in measured optimism.

Selection effects will not be equally strong at all percentiles of the distribution. All businesses can fail due to bad luck. Once a business is in financial distress, there is little to distinguish those with good ex ante prospects from weak. ${ }^{7}$ When good projects perform to their capability, the returns of the good prospects much exceed those in the weak. So it is at higher percentiles that optimism will have its greatest impact. To illustrate, suppose everyone is risk neutral, has the same intrinsic abilities, and there are no permanent income shocks. Initially, all are in paid-employment. Each period, earnings in paid employment are an independent draw from a uniform distribution with support $[L, H]$. At the end of the first period, some individuals identify a self-employment opportunity. This requires that capital must be installed, prior to the realisation of stochastic demand. It is reasonable to assume that access to capital is increasing in collateral availability and in other random factors. Due to moral hazard associated with default, borrowing never exceeds the level chosen by an individual able to self-finance. Those entering self-employment consequently install the maximum capital that a lender will permit. There are two levels of investment. With low

\footnotetext{
${ }^{7}$ By analogy, smoking predicts lung cancer but, once cancer is in its later stages, past smoking no longer predicts outcomes.
} 
capital stock, the distribution of net returns has support $\left[L^{*}, H^{*}\right], L^{*}<L, H^{*}>H, L^{*}+H^{*}<$ $L+H$. This prospect is riskier than paid-employment and as it has lower mean, is less attractive to a realist. With high capital installed, the support of self-employment returns is $\left[L^{*}-a, H^{*}+b\right], a, b>0, L^{*}-a+H^{*}+b>L+H$. Net returns in good states are boosted, but with low demand the business is overcapitalised and after loan repayment, net returns are reduced. ${ }^{8}$ Expected net returns are however higher for the better-capitalised business.

At the end of the first period, each person with a self-employment option selects it or else draws from the paid distribution again. Realists only enter self-employment if they have access to high capital. Everyone has equal ability, but half the population are intrinsic optimists. As discussed in the Introduction, it is plausible that bias is greater in assessing returns in self-employment. If optimism is sufficiently great, self-employment is chosen even when capital is low. ${ }^{9}$ Note further that for well-capitalised self-employment, earnings at percentile $P / 100$ are $s_{h}=P\left(H^{*}-L^{*}\right)+P(a+b)+L^{*}-a$ and for low-capitalised entry are, $s_{l}=P\left(H^{*}-L^{*}\right)+L^{*}$. So, $s_{h}-s_{l}=P(b+a)+a$.

Measured at a given percentile, the better-capitalised project always has higher returns, and the gap is increasing in the percentile. This property also applies to the comparison of optimists, who undertake both high and low capitalised self-employment, with realists who only undertake the latter. ${ }^{10}$

\footnotetext{
${ }^{8}$ For the full results, what matters is that higher capital increases the variance of returns. This could be because returns increase by the same proportion in every state. Lower returns in the worst states are not required.

${ }^{9}$ Even if in some sense optimism is the same in all domains, results still go through. Specifically, for optimists, the lowest $100 \lambda \%$ of outcomes are believed to have negligible chance of occurring, but above this level the distribution is uniform. This applies even to returns in paid employment. Relative to paid employment, optimism raises expected self-employment returns by $\lambda\left[\left(L^{*}+H^{*}\right)-(L+H)\right]$

${ }^{10}$ These effects are stronger still if there is a third period in which all revert to paid employment except the high earning self-employed
} 
Controlling for earnings as an employee, the selection effect will be greater at higher earnings percentiles.

To summarise, for those continuing as employees and controlling for past earnings, the correlation between past optimism and future earnings will be positive. For the selfemployed, the rational expectations effect will be offset by a selection effect that may be strong enough to create a negative correlation. These effects apply most clearly at higher earning percentiles and intermediate levels of optimism. Were it possible to instrument for intrinsic optimism the model implies that there would be no effects on those who never choose self-employment while the effect on the future self-employed would be larger than our estimates.

\section{Data source and method}

\subsection{BHPS survey and survey instrument}

The data used for analysis are taken from the British Household Panel Survey (BHPS). This is a nationally representative longitudinal survey that began in 1991, funded by the UK Economic and Social Research Council as a national and international multi-purpose research resource. A stratified random cluster sample of households was drawn from the population of British household postal addresses in Great Britain, and tracked annually thereafter. ${ }^{11}$ The questionnaire instrument includes a household schedule and a lengthy individual schedule that is completed separately by all adult household members present at each wave. This individual schedule covers a range of topics including demographic

\footnotetext{
${ }^{11}$ The far north of Scotland is excluded because of the prohibitive sampling costs. The original survey excludes Northern Ireland. Booster samples for Wales and Scotland recruited in 1999 and a sample for Northern Ireland recruited in 2001 are excluded from the analysis.
} 
characteristics, economic activity and finances. The original sample of 5000 households (comprising approximately 12000 individuals) was recruited in 1991. Follow-on rules establish the tracking of newly forming households involving originally enumerated household members. The present analysis uses the full 18 annual waves available from 1991 to $2008 .^{12}$

The sample used for the subsequent analysis is restricted to the original BHPS sample covering Great Britain and to those individuals who are either in paid employment or selfemployed. Self-employed is defined here as self-identified self-employed business ownership. This definition matches with UK taxation status, where the self-employed are required registering as responsible for own income tax payment, rather than being taxed through deductions made by an employer ("pay-as-you-earn”). The indicator is further refined from a questionnaire item asking whether the self-employed is a sole-trader, owner or part-owner of a business, as distinct from a freelancer or subcontractor. The latter are excluded from the definition of self-employed business owners and are dropped from the subsequent analysis. Approximately $80 \%$ of the self-employed are business owners. ${ }^{13}$

\subsection{The optimism measure}

\footnotetext{
${ }^{12}$ Sample attrition rates in the BHPS are generally low and certainly comparable to those achieved in other similar household panels. As is typical with household panels the highest attrition rate of individuals was between Waves 1 and 2 (12\%). Attrition between Waves 2 and 3 was 7\% of the original individuals and subsequently averaged $2.4 \%$ of the original sample between waves. In common with nearly all previously published research using this data source, attrition is assumed to be a random event. From 2009 onwards the BHPS sample has been merged into a much larger new longitudinal household study with further widening of scope, including biosocial analysis.

${ }^{13}$ A transition into self-employed business ownership is defined to have occurred if an individual's full-time or main economic status changes to that state. A small number of transitions into part-time self-employment alongside full-time or part-time paid employment are excluded from the futures group. We also delete all people that currently in paid-employment and were previously in the panel defined as self-employed. Therefore we control for multiple entries into self-employment for the futures group.
} 
The optimism measure is constructed from two questions on financial expectations and realizations, asked of all individuals in each year. The first is:

"Looking ahead, how do you think you yourself will be financially a year from now; better than you are now, worse than you are now, or about the same?”

Individuals who gave a valid response at year $t$ are then matched with their self-reported financial realisation at year $t+1$, obtained from the second question:

"Would you say that you yourself are better off, worse off or about the same financially than you were a year ago?”

The approach of Section 2 must be adapted to the categorical nature of the forecast and realisation data. The survey instrument asks for cardinal responses to both questions on three-point scales. One way to construct optimism from data of this type is to follow Das and van Soest (1997), Arabsheibani et al. (2000), Souleles (2004) and construct a five-point measure of forecast error, defined as the difference between the financial forecast $(o f t+1)$ at $t$, minus the financial realization at $t+1$. As optimism involves outcomes, to use it to explain outcomes there must be no overlap in the periods covered by dependent and independent variables. For those who will become self-employed (futures), the optimism estimate is computed over their period in prior paid employment. For those who never become selfemployed (nevers), it is computed over for the first half of the available periods in paidemployment (specifically, the next highest integer to the midpoint). The year prior to transition is excluded as the forecast may not have anticipated the switch to self-employment and there may be unusual shocks. 
One objection to this method is that the cardinalization of the error is potentially ambiguous. For example, forecasting better and achieving same is treated as equivalent to forecasting same and achieving worse. Although the five-point scale is commonly used, there is no fundamental defence of the procedure beyond saying it represents a convenient mapping from continuous but unobserved underlying forecasts and realizations. If the specification is wrong, it will make it harder to find optimism effects. At the second-stage, when the optimism measure is used to explain earnings, a cubic in optimism is estimated so as to allow effects to be very flexible in form.

Another potential criticism of the method is that, to the extent expectations are not rational, measured optimism will proxy for low underlying earning power and, therefore, be directly correlated with low earnings in the future. A negative association between optimism and earnings may simply reflect this effect rather than the influence of optimism on entry. To eliminate this possibility, when estimating the effect of optimism on earnings, two controls are included. The first is a fixed-effect estimate of earnings in paid-employment and the second a fixed-effect measure of categorical realisations in paid-employment. Thus, the effect of past optimism on future earnings is compared for individuals with the same earnings history, closing off the poor performance channel as the explanation of optimism effects. Were this mechanism still somehow to apply, it would generate a more negative effect for the never self-employed, but in fact we find positive effects there.

Although the categorical nature of the data is a drawback, the panel feature is an advantage allowing more precision in identifying intrinsic optimism. Averaged over a number of periods, the noise in the optimism measure will be diminished. To utilise this property, a linear fixed-effect regression is estimated 


$$
M_{i t}=\mathbf{X}_{i t}^{\prime} \boldsymbol{\beta}+z_{i}^{1}+\varepsilon_{i t}
$$

where $M_{i t}$ is the forecast error by individual $i$ at time $t . \mathbf{X}$ is a vector of time-varying demographic and other person specific characteristics of individual $i$, and $z_{i}^{1}$ is the individual fixed-effect coefficient. The individual fixed effects extracted from equation (9), $\hat{z}_{i}^{1}$, provide estimates of intrinsic optimism net of any environmental influences.

Descriptive statistics for the two sample groups, futures and nevers are in Table A1, with the corresponding full estimates of the optimism equation (equation 9) provided in Table A2. In total, there are 3138 futures observations from 618 individuals, so optimism is on average constructed from 5.1 observations per individual. For nevers there are 28,830 observations from 7367 individuals with optimism derived from an average of 3.9 waves per person. The average financial forecasts of futures exceed those of nevers, but average realizations are only marginally lower for futures. The forecast error is in the optimistic direction for both groups but futures are more optimistic than nevers. ${ }^{14}$ The rest of the empirical investigation tests whether this prior optimism is correlated with subsequent earnings in self-employment for futures and paid-employment for nevers.

\subsection{Earnings}

The gross monthly self-employment earnings of the 559 futures once transitioned into self-employed business ownership is computed from responses to two questions:

- How much net profit did you make from your share of the business or practice?

- How much did you earn (before tax) in the last twelve months or the most recent period for which you have figures?

\footnotetext{
${ }^{14}$ Nevers are identified as never being self-employed during the sample period. Some may enter selfemployment later, in which case the tendency is to under record the extent of the optimism difference with futures.
} 
The first question is asked of those individuals who draw up profit and loss accounts (approximately $80 \%$ of all futures) and the second for those who do not. From this information, the BHPS data release provides a derived construction of gross monthly earnings. To allow for any systematic difference in measurement error between the two response types, in the self-employment regressions a dummy is included for whether the measure is based on accounts. Self-employed individuals who are recorded as making a loss are coded with zero earnings meaning that the variable is left-hand censored. For this and other reasons described shortly quantile regressions are run. For nevers, gross monthly earnings are measured from payments of wages/salaries. Section 1 of Table 2 displays the distribution of gross monthly earnings for those in self-employment and those never becoming self-employed. Inspection of the percentiles of the earnings distribution reveals that the paid-employed have a relative advantage at the lower end, but at the very top end of the distribution the self-employed have a relative advantage. This earnings pattern will appeal to optimists.

\subsection{Final-Stage Equations}

The estimation of the effect of optimism on performance is implemented via separate second-stage regression equations for the two groups:

$$
E_{i t}=\sum_{j=1}^{3} \alpha_{j} \text { optimism }_{i}^{j}+\beta \text { pastearnings }_{i}+\lambda \text { pastrealizations }_{i}+\mathbf{X}_{i t}^{\prime} \boldsymbol{\delta}+\varepsilon_{i t}
$$

where $E_{i t}$ is gross monthly earnings, either for the self-employed business owner or for nevers over the second half of their employment period. For individual $i$, optimism $i$ is the fixed effect from the first-stage optimism equation, pastearnings $s_{i}$ is the fixed-effect from an earnings equation estimated over the same period for which optimism is estimated, and pastrealizations $_{i}$ from a similar categorical realization equation. The relationship between performance and optimism is allowed to take a cubic form in order to investigate the 
possibility of non-linearity discussed earlier and simulated in Table 1. To emphasise, there is no overlap in the periods over which the first-stage variables and $E_{i t}$ are measured. As discussed below, additional demographic and other personal control variables are in $\mathbf{X}$, including hours of work, with estimated coefficients $\boldsymbol{\delta}$.

By construction, the optimism measure, the fixed effects from equation (9), will tend to be negatively correlated with contemporaneous realizations and, to the extent that shocks are permanent, with future realizations and income. If optimism has a negative effect on earnings, it may seem that this is because optimism is merely an inverse proxy for earning power. This is not an issue since the earnings equation controls for prior realizations. The optimism effect is not due to extrapolation from past performance. ${ }^{15}$ Moreover, within the BHPS the categorical realization variable is not the only measure of earnings power available, there is also the self-reported wage. This should be a better measure than the realizations variable that concerns an individual's overall financial situation and not just their earnings from earlier paid-employment. The procedure is, therefore, to estimate a fixed effect log of hourly wages equations (Table A3 in the Appendix) for individuals in all paid employment periods for which optimism is measured. The individual fixed effect is then extracted and used as a further control in the self-employed earnings equations (10) to proxy for intrinsic earnings ability. These fixed effects are noisy estimates of an individual's intrinsic earnings ability and it is, therefore, possible that realizations also have something to contribute to the estimation of earning power. As noted, the individual fixed effects from a linear fixed-effect realization equation is included as a further control in the self-employed gross monthly earning equation (Table A4 in the Appendix). That this procedure succeeds in removing mechanical effects is indicated by the relation between optimism and earnings

\footnotetext{
${ }^{15}$ The greater the extent to which past realizations are due to permanent shocks, the lower might expectations be and thus lower optimism implies worse performance contrary to the self-employment finding.
} 
being positive for the nevers. This is consistent with recorded optimism sometimes reflecting bad luck. Individuals made rational forecasts but realisations were low by chance. These individuals should do better in the future due to mean reversion. For futures this effect may still be present but now the effect of intrinsic optimism on entry more than offsets the rational expectations effect.

Section 2 of Table 2 summarises the descriptive statistics for a set of control covariates that are used in the subsequent gross monthly earnings equations for our two samples. It is of note that the self-employed who were futures in the first stage are much more likely to be male, reflecting the lower proportion of women amongst the stock of selfemployed in the UK. The self-employed are less likely to hold university/college degrees than nevers but are more likely to have dependent children, to be home owners and married. Just over $18 \%$ of self-employed respondents report leaving compulsory schooling with no formal qualifications compared to $16 \%$ of the employed. Home ownership and wealth has also been found to be correlated with self-employment activity, through their role in providing financial capital and relaxing liquidity constraints (Black, de Meza and Jeffreys, 1996, Hurst and Lusardi, 2004; Henley, 2007). As noted, high levels of home ownership are reported by the self-employed, with approximately 69\% reporting a mortgage debt on their property. Labour market experience is captured through the inclusion of an employment tenure variable in quadratic form. ${ }^{16}$ On average futures have nearly 4 years of employment tenure and nevers 5.7 years. For the self-employed, prior experience may, however, be provided indirectly through parental role models (Fairlie and Robb, 2007; Colombier and Masclet, 2008). Parental business ownership experience is include as a control. Over threequarters did not have a self-employed parent, with $22 \%$ reporting that one or both parents

\footnotetext{
${ }^{16}$ Computed in the usual manner as age minus approximate years of pre-school and schooling.
} 
were self-employed. The self-employed also work just over 9 hours longer per week than nevers.

\section{Results}

This section reports separate multivariate regressions of the form of (10) showing the relationship between gross monthly earnings and optimism for futures and nevers. Quantile regressions are estimated because the preceding theoretical discussion points to an optimismearnings relationship that varies across the earnings distribution, with optimism effects more apparent at higher outcomes. Moreover, as noted, gross monthly earnings of the selfemployed are left-censored at zero. Quantile regression methods will provide results that are robust to this data feature.

Key coefficients for the second-stage regressions are reported in Table 3 (the full tables are in the Appendix, A5a and A5b). The table reports standard errors which are asymptotically valid under heteroscedasticity and which are clustered in order to control for multiple observations per individual (see Machado and Santos Silva, 2000; Machado and Santos Silva, 2011; Machado et al., 2014). ${ }^{17}$

Figure 1 plots the estimated relationships between intrinsic optimism and earnings from (8) for selected percentiles. Mean optimism is standardised to zero. On this scale, the rational expectation forecast (zero mean error) is -0.25 for the self-employed. The plotted range of optimism covers $97 \%$ of observations. For the self-employed, linear and quadratic

\footnotetext{
${ }^{17}$ An alternative is to bootstrap.
} 
functional forms are rejected in favour of more flexible cubics. ${ }^{18}$ The upper plots are shown how the fitted values of earnings vary with optimism for the self-employed (cubics) and employees (linear). In the lower part of the figure, the slope of the self-employment earnings function with respect to optimism is plotted with associated confidence intervals. As suggested by the theory, the higher the percentile, the greater the relative earnings of the selfemployed.

The main finding is that for the self-employed, except at the belief extremes, greater intrinsic optimism is associated with lower earnings. At high quantiles, effects are highly significant. They are also large. The most optimistic of the self-employed earn some $25 \%$ less than the least optimistic, measured at their respective $75^{\text {th }}$ earnings percentiles. For employees, the relationship is reversed. Higher intrinsic optimism is associated with increased earnings. These results are consistent with expectations involving both rational and psychological elements. To the extent that the optimism measure captures temporary negative income shocks, it will be associated with improved subsequent performance. This is likely to be the main effect in paid employment. To the extent that measured optimism reflects systematic psychological bias, entry errors arise, imparting a negative relationship between optimism and self-employment. ${ }^{19}$ The self-employment finding might also reflect that optimists are relatively less successful at running businesses than as employees. This though should be revealed at belief extremes where selection effects do not apply, and it is here that the negative effect disappears. Optimism does not seem to have differential effects on operating performance.

\footnotetext{
${ }^{18}$ Results are similar if the relationship is estimated as piecewise linear.

${ }^{19}$ Including graduate/optimism interaction does not yield significant coefficients suggesting optimism effects are not restricted to the unsophisticated.
} 
Full estimates from the quantile regressions are reported in Table A5a and A5b for futures and for nevers, respectively, with results provided for the $25^{\text {th }}, 50^{\text {th }}, 75^{\text {th }}, 90^{\text {th }}$ and $95^{\text {th }}$ percentiles of the self-employed and employee earnings distributions. Turning firstly and briefly to the control variables, there is a positive association between earnings and age, although the effect decelerates. ${ }^{20}$ Being male boosts second-stage income of both futures and nevers, with this effect increasing at higher percentiles of the earnings distributions. As gender is part of the first-stage earnings fixed effects, these coefficients indicate that gender plays a greater role as careers progress. Possession of a university (degree) qualification is associated with higher subsequent earnings for both groups, but this effect is only statistically significant at the $95^{\text {th }}$ percentile of the earnings distribution for futures. Formal qualifications may be less salient for success in starting a business. Finally, the proxy for earnings power in prior employment is strongly and positively associated with subsequent earnings. This effect is not statistically significant at the $25^{\text {th }}$ percentile for futures, suggesting that once businesses are in the "emergency room” provenance does not matter. This provides further support to the proposition that optimism effects only appear at higher quantiles.

Although earnings in paid employment are generally found to be over reported relative to those in self-employment (Astebo and Chen (2014), Hurst, Li and Pugsley (2014)) it is nevertheless of interest to see how much of the measured difference is due to intrinsic optimism. The most straightforward way to accomplish this is to run separate earnings regressions for the two groups, with the intrinsic optimism variable put on a common basis by means of a pooled first-stage regression. Computing the difference in the contribution of mean optimism in the two earnings equations, $10.6 \%$ of the mean difference in income is due to intrinsic optimism.

\footnotetext{
${ }^{20}$ Age and other time varying variables may affect optimism. Entering such variables at both stages nets out there contribution via the optimism channel.
} 


\section{Optimism, Divorce and Smoking}

If the financial optimism measure captures an innate psychological trait, then it should be correlated with other aspects of behaviour. As a test for validity, results are provided for a context involving rather similar issues - the relationship between optimism and future divorce.

Viewed from the perspective of search theory, marriage has something in common with entry into self-employment. The issue is to decide when a sufficiently good prospect has arrived. The optimism perspective is captured by the adage "Marry in haste, repent at leisure”. Optimists overestimate match quality, eventually realise that the marriage is a mistake, and are therefore more likely to divorce. ${ }^{21}$ To test this, the optimism of the married, measured as the five-point difference between forecast and realisation, is regressed on a dummy for will be divorced in the future. The results are the first column of Table A6. Divorce is highly significant, but as it stands, it could be argued that the effect is due to unlucky negative income shocks triggering divorce rather than intrinsic optimism. To counter this, two further equations are estimated. One examines whether people who are currently married but will divorce in the future have higher expectations than those who do not divorce. A parallel equation examines whether future divorcees have worse realisations. The difference in the two future marital states is tested for statistical significance to determine whether future divorcees are more optimistic. The two-equation procedure makes it possible to reject the negative shock interpretation.

\footnotetext{
${ }^{21}$ Optimists might overate their own attractiveness and therefore wait longer to get married. Nevertheless, matches based on one party overestimating their worth are also likely to be unsatisfactory and therefore more likely to terminate.
} 
Column 2 of Table A6 presents the expectation equation. The main issue is to determine whether those who will divorce in the future have higher prior expectations. To this end, the first row is the coefficient on a dummy variable for future-divorcee status. Divorce itself has repercussions on income and may therefore affect expectations. A series of dummies is introduced to take these effects into account. There are dummies for year before divorce and year of divorce and for divorced status. Similarly, there is a dummy for year of remarriage should this occur and for remarried status. Future-divorcees have significantly higher expectations, as shown in the coefficient estimate being significant at the $1 \%$ level. So an optimism effect cannot just be the result of income collapse. The final element is to check that an intrinsic optimism is present and not merely explained by income shocks post-divorce. Column 3 provides the realisation equation that matches the expectation equation. Futuredivorcees earn slightly more than non-divorcees, but the difference is not significant. The dummy coefficent in the expectation equation is greater than that in the realisation equation, significant at the $1 \%$ level. So it can be concluded that prior intrinsic optimism is associated with divorce.

As a further validity check these equations also reveal that smokers have very significantly higher financial optimism. Although increased smoking is associated with lower income at a marginal level of significance, optimism is not just the result of low income. Heavy smokers also have significantly higher expectations than those who do not smoke, given the same observables. Financial optimists tend to assume the worst will not happen. This psychology appears to transfer to the consequences of smoking. This suggests that the optimism measure does at least partially capture a psychological trait.

\section{Conclusion}


This paper finds that optimism measured prior to entry is associated with lower earnings in self-employment. For employees, greater optimism is associated with higher subsequent earnings. These results are in line with two features of expectations. An intrinsic optimistic bias leads to mistaken entry into self-employment while prior measured optimism due to bad luck is correlated with higher earnings. The inclusion of past earnings as a control means the results are not the consequence of permanent income shocks leading individuals to try a different employment mode. The negative correlation between optimism and selfemployment earnings could be a treatment rather than a selection effect. Optimism may directly affect performance in ways that are absent in salaried employment. Perhaps the selfemployed have more discretion than employees and therefore it is more important that their decisions are based on a realistic appraisal of alternatives. There are three reasons for doubting that treatment effects are responsible for the findings. First, the implication that bias lowers productivity is that realists would do best, but self-employed pessimists earn more than realists. Second, at the extremes of optimism and pessimism, where theoretically the selection effect does not operate, optimism effects are the same as in paid employment. Finally, if entrants knew that optimism is a disadvantage in self-employment, employees would on average be more optimistic than the self-employed, contrary to the evidence.

The results of this paper are relevant to the question of whether becoming selfemployed increases or decreases financial well-being. Levine and Rubinstein (2013) have recently cast some doubt on whether all forms of self-employment diminish earnings. They distinguish between business types. The owners of incorporated businesses, shown to be most likely to be engaged in true entrepreneurial activity, on average experience a boost average income, gross of the cost of self-finance. It is starting an unincorporated businesses that is 
associated with a decline in income. Even for the incorporated, these findings do not preclude an optimism effect. If those setting up incorporated businesses are realistic, risk-neutral and non-pecuniary aspects are unimportant, the only acceptable opportunities yield expected returns at least as high as employee earnings. Starting an incorporated business, therefore, raises expected income. Risk aversion and the unmeasured cost of self-finance further augment the tendency for the income of the owners of incorporated businesses to exceed that of observationally identical employees. ${ }^{22}$ As it is not easy to determine by how much more the income of owners of incorporated businesses should on average exceed that of comparable employees, a positive difference does not preclude optimism leading to excess entry.

This paper estimates the equilibrium relationship between self-employment earnings and prior optimism rather than the equilibrium earnings difference between the self-employed and employees. The negative correlation between optimism and self-employment earnings suggests that at least some business entry is the result of mistaken expectations. There will also exist pessimists who do not enter but would have done had they been more realistic. This too is an error, though of the opposite kind.

\section{References}

Arabsheibani, G., de Meza, D., Maloney, J. and Pearson, B. (2000). “And a vision appeared unto them of a great profit: Evidence of self-deception among the self-employed." Economics Letters 67(1): 35-41.

Åstebro, T, and J Chen (2014) "The Entrepreneurial Earnings Puzzle: Mismeasurement or Real?” Journal of Business Venturing 29(1): 88-105.

\footnotetext{
${ }^{22}$ Non-pecuniary benefits of self-employment, as in Hurst and Pugsley (2010) work in the direction of lowering the equilibrium income of business owners; likewise the effect of rational experimentation as in Jovanovic (1982).
} 
Åstebro, T. (2003). "The return to independent invention: Evidence of unrealistic optimism, risk seeking or skewness loving?” Economic Journal 113(484): 226-239.

Åstebro, T., S.A. Jeffrey and G.K. Adomdza (2007). “Inventor perseverance after being told to quit: The role of cognitive biases.” Journal of Behavioral Decision Making 20(3): 253272.

British Household Panel Survey. 1991-2009. UK Data Service.

http://discover.ukdataservice.ac.uk/catalogue?sn=5151 (accessed January 17, 2015).

Black, J.M., De Meza, D., Jeffreys D. (1996). "House prices, the supply of collateral and the enterprise economy.” Economic Journal 106: 60 - 75.

Brunnermeier, Markus and Jonathan Parker (2005), \Optimal Expectations," American Economic Review, 95 (4), 1092-1118.

Camerer, C. and Lovallo, D. (1999). "Overconfidence and excess entry: an experimental approach.” American Economic Review 89(1): 306-318.

Cassar, G. (2010). "Are individuals entering self-employment overly-optimistic? An empirical test of plans and projections on nascent entrepreneur expectations.” Strategic Management Journal 31(8): 822-840.

Columbier, N. and Masclet, D. (2008). "Intergenerational correlation in self-employment: some further evidence from French ECHP data.” Small Business Economics 30(4): 423-437.

Cooper, A.C., Woo, C.Y. and Dunkelberg, W.C. (1988). "Entrepreneurs' perceived chances for success.” Journal of Business Venturing 3(2): 97-108.

Dawson, C., D. de Meza, A. Henley \& R. Arabsheibani (2014). "Entrepreneurship: Cause and Consequence of Financial Optimism." Journal of Economics and Management Strategy 23(4): 717-742.

Das, J.W.M., and Van Soest, A. (1997). "Expected and realized income changes: Evidence from the Dutch Socio-Economic Panel.” Journal of Economic Behavior and Organization 32(1): 137-154

de Meza, D. and Southey, C. (1996). "The borrower's curse: Optimism, finance and entrepreneurship.” The Economic Journal 106(435): 375-386.

Fairlie, R.W. and Robb, A.M. (2007). "Families, human capital and small business: evidence from the Characteristics of Business Owners Survey." Industrial and Labor Relations Review 60(2): 225-24.

Gervais, S. and Odean, T. (2001). "Learning to be overconfident.” The Review of Financial Studies 89(1): 1-27.

Hamilton, B.H. (2000). "Does entrepreneurship pay: An empirical analysis of the returns of self-employment.” The Journal of Political Economy 108(3): 604-631.

Hamilton, B.H. and Papageorge, N.W. and Pande, N., (2014) “The Right Stuff? Personality and Entrepreneurship” mimeo, available at SSRN: http://ssrn.com/abstract=2438944 
Henley, A. (2007). "Entrepreneurial aspiration and transition into self-employment: evidence from British longitudinal data.” Entrepreneurship and Regional Development 19(3): 253-280.

Hurst, E. G. Li and B. Pugsley (2014) “Are Household Surveys Like Tax Forms: Evidence from Income Underreporting of the Self Employed" Review of Economics and Statistics, 96(1), 19-33

Hurst, E. and Lusardi, A-M. (2004). "Liquidity constraints, household wealth and entrepreneurship.” Journal of Political Economy 112(2): 319-347.

Hurst, E. and B. Pugsley (2010): “Non Pecuniary Benefits of Small Business Ownership”, mimeo, University of Chicago.

Hvide, H.K. (2002). "Pragmatic beliefs and overconfidence.” Journal of Economic Behavior and Organization 48(1): 15-29.

Hvide, Hans K., and Georgios A. Panos (2014) "Risk Tolerance and Entrepreneurship." Journal of Financial Economics 111(1): 200-23.

Jovanovic, B. (1982). "Selection and the evolution of industry.” Econometrica 50(3): 649670.

Levine, R., \& Rubinstein, Y. (2013). "Smart and Illicit: Who Becomes an Entrepreneur and Does it Pay?” National Bureau of Economic Research Working Paper No. w19276.

Malmendier,U and G. Tate (2008) "Who Makes Acquisitions? CEO Overconfidence and the Market's Reaction Journal of Financial Economics vol. 89(1), pp. 20-43.

Machado, J.A.F. and Santos Silva, J.M.C. (2000). “Glejser's Test Revisited.” Journal of Econometrics 97: 189-202.

Machado, J.A.F. and Santos Silva, J.M.C. (2011). "Quantile regression and heteroskedasticity” Working aper, available http://privatewww.essex.ac.uk/ jmcss/JM_JSS.pdf (accessed December 17, 2014).

Machado, J. A. F., Parente, P. M., \& Silva, J. S. (2014). "qreg2: Stata module to perform quantile regression with robust and clustered standard errors." Statistical Software Components.

Moskowitz, T. J. and Vissing-Jorgensen, A. (2002) "The returns to entrepreneurial investment: A private equity premium puzzle?” American Economic Review 92(4):745-778.

Puri, M. and Robinson, D.T. (2007). “Optimism and economic choice.” Journal of Financial Economics 86(1): 71-99.

Puri, M. and Robinson, D.T. (2013). "The economic psychology of entrepreneurship and family business.” Journal of Economics and Management Strategy 22(2): 207-444.

Souleles, N.S. (2004). "Expectations, heterogeneous forecast errors and consumption: micro evidence from the Michigan consumer sentiment surveys." Journal of Money, Credit and Banking 36(1): 39-72. 
Trivers, R. L. (2000). “The elements of a scientific theory of self-deception.” Annals of New York Academy of Sciences 907: 114-192.

Weinstein N. 1980. “Unrealistic optimism about future life events.” Journal of Personality and Social Psychology 36(5): 806-820. 
Table 2: Descriptive statistics

\begin{tabular}{lcc}
\hline Section 1 & Self-Employed & Paid-Employed \\
\hline Gross monthly earnings (in $£$ ) & & \\
Mean & 1381.48 & 1733.92 \\
$25^{\text {th }}$ percentile & 291.67 & 958.75 \\
$50^{\text {th }}$ percentile & 833.33 & 1499.15 \\
$75^{\text {th }}$ percentile & 1583.33 & 2208.33 \\
$90^{\text {th }}$ percentile & 3031.00 & 3097.38 \\
$95^{\text {th }}$ percentile & 4583.33 & 3788.92
\end{tabular}

\begin{tabular}{|c|c|c|c|c|c|}
\hline \multirow{2}{*}{$\begin{array}{l}\text { Section } 2 \\
\text { Variable }\end{array}$} & \multirow[b]{2}{*}{ Description } & \multicolumn{2}{|c|}{ Self-Employed } & \multicolumn{2}{|c|}{ Paid-Employed } \\
\hline & & Mean & Std. Dev. & Mean & Std. Dev. \\
\hline \multicolumn{6}{|l|}{ Whether Draws up } \\
\hline \multicolumn{6}{|l|}{ Profit/Loss Accounts: } \\
\hline Draws up accounts & & 0.823 & & - & \\
\hline Does not draw up accounts & $\begin{array}{l}\text { (reference } \\
\text { category) }\end{array}$ & 0.089 & & - & \\
\hline Not yet but will be & & 0.089 & & - & \\
\hline \multicolumn{6}{|l|}{ Paid-Employment } \\
\hline \multicolumn{6}{|l|}{ Performance Controls: } \\
\hline Pastearnings & & 0.024 & 0.740 & 0.006 & 0.376 \\
\hline Pastrealizations & & -0.003 & 0.631 & -0.005 & 0.799 \\
\hline \multicolumn{6}{|l|}{ Health: } \\
\hline Health-excellent & & 0.267 & & 0.250 & \\
\hline Health-good & & 0.496 & & 0.509 & \\
\hline Health-other & $\begin{array}{l}\text { (reference } \\
\text { category) }\end{array}$ & 0.237 & & 0.241 & \\
\hline \multicolumn{6}{|l|}{ Demographics: } \\
\hline Age (years) & & 42.48 & 10.01 & 42.36 & 10.58 \\
\hline Age $^{2}$ & & 1905.1 & 862.3 & 1906.0 & 898.3 \\
\hline Male & & 0.686 & & 0.482 & \\
\hline \multicolumn{5}{|l|}{ Marital Status and } & \\
\hline Single, never married & $\begin{array}{l}\text { (reference } \\
\text { category) }\end{array}$ & 0.100 & & 0.135 & \\
\hline Widowed/divorced/separated & & 0.060 & & 0.090 & \\
\hline $\begin{array}{l}\text { Married/cohabiting, partner } \\
\text { employed }\end{array}$ & & 0.690 & & 0.661 & \\
\hline $\begin{array}{l}\text { Married/cohabiting, partner } \\
\text { not employed }\end{array}$ & & 0.150 & & 0.113 & \\
\hline $\begin{array}{l}\text { Number of dependent } \\
\text { children in household }\end{array}$ & & 0.824 & 1.063 & 0.622 & 0.916 \\
\hline Educational attainment: & & & & & \\
\hline University/college degree & & 0.157 & & 0.181 & \\
\hline $\begin{array}{l}\text { Vocational college } \\
\text { qualification }\end{array}$ & & 0.087 & & 0.078 & \\
\hline A-levels & & 0.261 & & 0.216 & \\
\hline O-levels/GCSEs & & 0.314 & & 0.363 & \\
\hline
\end{tabular}




\begin{tabular}{|c|c|c|c|c|c|}
\hline No qualifications & $\begin{array}{l}\text { (reference } \\
\text { category) }\end{array}$ & 0.181 & & 0.163 & \\
\hline \multicolumn{6}{|l|}{ Housing tenure: } \\
\hline Outright owner & & 0.183 & & 0.173 & \\
\hline Own with mortgage & & 0.693 & & 0.678 & \\
\hline Private sector rental & & 0.075 & & 0.068 & \\
\hline Social sector rental & $\begin{array}{l}\text { (reference } \\
\text { category) }\end{array}$ & 0.048 & & 0.081 & \\
\hline \multicolumn{6}{|l|}{$\begin{array}{l}\text { Parental background at age } \\
\text { 14: }\end{array}$} \\
\hline Both parents self-employed & & 0.034 & & 0.012 & \\
\hline Father self-employed & & 0.159 & & 0.103 & \\
\hline Mother self-employed & & 0.029 & & 0.021 & \\
\hline Neither parent self-employed & $\begin{array}{l}\text { (reference } \\
\text { category) }\end{array}$ & 0.778 & & 0.864 & \\
\hline \multicolumn{6}{|l|}{ Labour Market } \\
\hline Job tenure (years) & & 3.98 & 4.64 & 5.68 & 6.56 \\
\hline Job tenure ${ }^{2}$ & & 37.33 & 98.94 & 75.30 & 168.38 \\
\hline Usual hours worked per week & & 43.73 & 16.41 & 34.56 & 9.59 \\
\hline $\begin{array}{l}\text { Usual hours worked per } \\
\text { week }^{2}\end{array}$ & & 2181.4 & 1522.1 & 1286.6 & 643.6 \\
\hline Holding a second job & & 0.095 & & 0.072 & \\
\hline $\mathrm{N}$ & & $\begin{array}{r}1 \\
\text { (559 in }\end{array}$ & $\begin{array}{l}4 \\
\text { iduals) }\end{array}$ & $\begin{array}{r}2 \\
(6057 \mathrm{i}\end{array}$ & duals) \\
\hline
\end{tabular}

Source: authors’ tabulations from BHPS 1991-2008 
Table 3: Derivatives of gross monthly earnings with respect to optimism

\begin{tabular}{|c|c|c|c|c|c|c|c|c|c|c|c|c|c|}
\hline & \multicolumn{13}{|c|}{ Standardised Optimism Scale $(\mu=0$ and $\sigma=1)$} \\
\hline $\begin{array}{c}\text { Gross } \\
\text { Monthly } \\
\text { Earnings } \\
\text { Quantile }\end{array}$ & $\begin{array}{c}-2 \\
\text { Extreme } \\
\text { Pessimism }\end{array}$ & -1.5 & -1 & -0.75 & -0.5 & -0.25 & 0 & +0.25 & +0.5 & +0.75 & +1 & +1.5 & $\begin{array}{c}+2 \\
\text { Extreme } \\
\text { Optimism }\end{array}$ \\
\hline \multicolumn{14}{|c|}{ Self-Employed } \\
\hline $25^{\text {th }}$ & $\begin{array}{c}64.0 \\
(62.6)\end{array}$ & $\begin{array}{c}51.2 \\
(48.7)\end{array}$ & $\begin{array}{c}39.1 \\
(55.2)\end{array}$ & $\begin{array}{c}33.4 \\
(59.7)\end{array}$ & $\begin{array}{c}27.8 \\
(63.3)\end{array}$ & $\begin{array}{c}22.3 \\
(65.4)\end{array}$ & $\begin{array}{c}17.1 \\
(66.1)\end{array}$ & $\begin{array}{c}12.1 \\
(65.9)\end{array}$ & $\begin{array}{c}7.2 \\
(65.7)\end{array}$ & $\begin{array}{c}2.5 \\
(66.9)\end{array}$ & $\begin{array}{c}-2.0 \\
(71.2)\end{array}$ & $\begin{array}{l}-10.5 \\
(94.3)\end{array}$ & $\begin{array}{c}-18.2 \\
(138.3)\end{array}$ \\
\hline $50^{\text {th }}$ & $\begin{array}{c}254.7^{* * * *} \\
(67.4)\end{array}$ & $\begin{array}{c}79.9 \\
(57.4)\end{array}$ & $\begin{array}{l}-47.1 \\
(71.3)\end{array}$ & $\begin{array}{l}-92.7 \\
(78.0)\end{array}$ & $\begin{array}{l}-126.3 \\
(82.7)\end{array}$ & $\begin{array}{c}-148.0^{*} \\
(85.0)\end{array}$ & $\begin{array}{c}-157.7^{*} \\
(85.3)\end{array}$ & $\begin{array}{c}-155.4^{*} \\
(84.2)\end{array}$ & $\begin{array}{c}-141.2^{*} \\
(83.1)\end{array}$ & $\begin{array}{l}-115.0 \\
(83.9)\end{array}$ & $\begin{array}{l}-76.9 \\
(89.2)\end{array}$ & $\begin{array}{c}35.3 \\
(120.3)\end{array}$ & $\begin{array}{c}195.3 \\
(179.5)\end{array}$ \\
\hline $75^{\text {th }}$ & $\begin{array}{c}489.5^{* * *} \\
(95.1)\end{array}$ & $\begin{array}{c}164.9^{* *} \\
(83.5) \\
\end{array}$ & $\begin{array}{l}-77.1 \\
(95.8) \\
\end{array}$ & $\begin{array}{c}-167.1 \\
(101.7) \\
\end{array}$ & $\begin{array}{c}-236.3^{* *} \\
(105.1) \\
\end{array}$ & $\begin{array}{c}-285.0^{* * *} \\
(105.4) \\
\end{array}$ & $\begin{array}{c}-312.9 * * * \\
(102.4) \\
\end{array}$ & \begin{tabular}{|c|}
$-320.2^{* * *}$ \\
$(96.7)$ \\
\end{tabular} & $\begin{array}{c}-306.8^{* * *} \\
(89.3) \\
\end{array}$ & $\begin{array}{c}-272.7^{* * *} \\
(82.6) \\
\end{array}$ & $\begin{array}{c}-218.0 * * * \\
(80.6)\end{array}$ & $\begin{array}{c}-46.4 \\
(107.5) \\
\end{array}$ & $\begin{array}{c}207.8 \\
(176.7) \\
\end{array}$ \\
\hline $90^{\text {th }}$ & $\begin{array}{c}450.2 \\
(286.8)\end{array}$ & $\begin{array}{c}-11.6 \\
(195.2)\end{array}$ & $\begin{array}{c}-344.6^{*} \\
(188.4)\end{array}$ & $\begin{array}{c}-462.9 * * \\
(198.4)\end{array}$ & $\begin{array}{c}-548.9 * * * \\
(207.1)\end{array}$ & $\begin{array}{c}-602.8^{* * *} \\
(210.4)\end{array}$ & $\begin{array}{c}-624.4^{* * *} \\
(206.4)\end{array}$ & $\begin{array}{c}-613.9 * * * \\
(194.7)\end{array}$ & $\begin{array}{c}-571.1^{* * *} \\
(176.0)\end{array}$ & $\begin{array}{c}-496.2^{* * *} \\
(153.4)\end{array}$ & $\begin{array}{c}-389.1^{* * *} \\
(135.0)\end{array}$ & $\begin{array}{c}-78.2 \\
(168.9)\end{array}$ & $\begin{array}{c}361.4 \\
(316.4)\end{array}$ \\
\hline $95^{\text {th }}$ & $\begin{array}{c}611.7^{* * *} \\
(202.0) \\
\end{array}$ & $\begin{array}{c}-29.6 \\
(157.7) \\
\end{array}$ & $\begin{array}{c}-500.9^{* * *} \\
(172.1) \\
\end{array}$ & $\begin{array}{c}-672.7 * * * \\
(182.7) \\
\end{array}$ & $\begin{array}{c}-801.9^{* * *} \\
(189.7) \\
\end{array}$ & $\begin{array}{c}-888.7^{* * *} \\
(191.8) \\
\end{array}$ & $\begin{array}{c}-932.8^{* * *} \\
(189.1) \\
\end{array}$ & $\begin{array}{c}-934.5^{* * *} \\
(183.1) \\
\end{array}$ & $\begin{array}{c}-893.6^{* * *} \\
(177.5) \\
\end{array}$ & $\begin{array}{c}-810.2^{* * *} \\
(177.9) \\
\end{array}$ & $\begin{array}{c}-684.2^{* * *} \\
(191.6) \\
\end{array}$ & $\begin{array}{c}-304.7 \\
(275.2) \\
\end{array}$ & $\begin{array}{c}245.1 \\
(428.5) \\
\end{array}$ \\
\hline \multicolumn{14}{|c|}{ Paid-Employed } \\
\hline $25^{\text {th }}$ & $\begin{array}{c}29.8^{* *} \\
(11.7)\end{array}$ & $\begin{array}{l}29.8^{* *} \\
(11.7)\end{array}$ & $\begin{array}{l}29.8^{* *} \\
(11.7)\end{array}$ & $\begin{array}{l}29.8^{* *} \\
(11.7)\end{array}$ & $\begin{array}{l}29.8^{* *} \\
(11.7)\end{array}$ & $\begin{array}{l}29.8^{* *} \\
(11.7)\end{array}$ & $\begin{array}{c}29.8^{* *} \\
(11.7)\end{array}$ & $\begin{array}{l}29.8^{* *} \\
(11.7)\end{array}$ & $\begin{array}{l}29.8^{* *} \\
(11.7)\end{array}$ & $\begin{array}{c}29.8^{* *} \\
(11.7)\end{array}$ & $\begin{array}{c}29.8^{* *} \\
(11.7)\end{array}$ & $\begin{array}{c}29.8^{* *} \\
(11.7)\end{array}$ & $\begin{array}{l}29.8^{* *} \\
(11.7)\end{array}$ \\
\hline $50^{\text {th }}$ & $\begin{array}{c}27.4^{* *} \\
(13.0)\end{array}$ & $\begin{array}{c}27.4^{* *} \\
(13.0)\end{array}$ & $\begin{array}{c}27.4^{* *} \\
(13.0)\end{array}$ & $\begin{array}{l}27.4^{* *} \\
(13.0)\end{array}$ & $\begin{array}{c}27.4^{* *} \\
(13.0)\end{array}$ & $\begin{array}{c}27.4^{* *} \\
(13.0)\end{array}$ & $\begin{array}{c}27.4^{* *} \\
(13.0)\end{array}$ & $\begin{array}{c}27.4^{* *} \\
(13.0)\end{array}$ & $\begin{array}{c}27.4^{* *} \\
(13.0)\end{array}$ & $\begin{array}{c}27.4^{* *} \\
(13.0)\end{array}$ & $\begin{array}{c}27.4^{* *} \\
(13.0)\end{array}$ & $\begin{array}{c}27.4^{* *} \\
(13.0)\end{array}$ & $\begin{array}{l}27.4^{* *} \\
(13.0)\end{array}$ \\
\hline $75^{\text {th }}$ & $\begin{array}{c}63.5^{* * * *} \\
(20.2)\end{array}$ & $\begin{array}{c}63.5^{* * *} \\
(20.2)\end{array}$ & $\begin{array}{c}63.5^{* * *} \\
(20.2)\end{array}$ & $\begin{array}{c}63.5^{* * * *} \\
(20.2)\end{array}$ & $\begin{array}{c}63.5^{* * * *} \\
(20.2)\end{array}$ & $\begin{array}{c}63.5^{* * * *} \\
(20.2)\end{array}$ & $\begin{array}{c}63.5^{* * * *} \\
(20.2)\end{array}$ & $\begin{array}{c}63.5^{* * * *} \\
(20.2)\end{array}$ & $\begin{array}{c}63.5^{* * * *} \\
(20.2)\end{array}$ & $\begin{array}{c}63.5^{* * * *} \\
(20.2)\end{array}$ & $\begin{array}{c}63.5^{* * *} \\
(20.2)\end{array}$ & $\begin{array}{c}63.5^{* * *} \\
(20.2)\end{array}$ & $\begin{array}{c}63.5^{* * *} \\
(20.2)\end{array}$ \\
\hline $90^{\text {th }}$ & $\begin{array}{l}87.9 * * \\
(35.8) \\
\end{array}$ & $\begin{array}{c}87.9^{* *} \\
(35.8)\end{array}$ & $\begin{array}{l}87.9 * * \\
(35.8) \\
\end{array}$ & $\begin{array}{l}87.9 * * \\
(35.8)\end{array}$ & $\begin{array}{l}87.9^{* *} \\
(35.8)\end{array}$ & $\begin{array}{l}87.9 * * \\
(35.8)\end{array}$ & $\begin{array}{c}87.9 * * \\
(35.8)\end{array}$ & $\begin{array}{l}87.9^{* *} \\
(35.8)\end{array}$ & $\begin{array}{c}87.9 * * \\
(35.8)\end{array}$ & $\begin{array}{c}87.9 * * \\
(35.8)\end{array}$ & $\begin{array}{c}87.9 * * \\
(35.8)\end{array}$ & $\begin{array}{c}87.9^{* *} \\
(35.8)\end{array}$ & $\begin{array}{l}87.9 * * \\
(35.8)\end{array}$ \\
\hline $95^{\text {th }}$ & $\begin{array}{c}129.6^{* * * *} \\
(43.5)\end{array}$ & $\begin{array}{c}129.6^{* * *} \\
(43.5)\end{array}$ & $\begin{array}{c}129.6 * * * \\
(43.5)\end{array}$ & $\begin{array}{c}129.6^{* * *} \\
(43.5)\end{array}$ & $\begin{array}{c}129.6^{* * *} \\
(43.5)\end{array}$ & $\begin{array}{c}129.6^{* * *} \\
(43.5)\end{array}$ & $\begin{array}{c}129.6^{* * *} \\
(43.5)\end{array}$ & $\begin{array}{c}129.6^{* * *} \\
(43.5)\end{array}$ & $\begin{array}{c}129.6^{* * *} \\
(43.5)\end{array}$ & $\begin{array}{c}129.6^{* * *} \\
(43.5)\end{array}$ & $\begin{array}{c}129.6^{* * *} \\
(43.5)\end{array}$ & $\begin{array}{c}129.6^{* * *} \\
(43.5)\end{array}$ & $\begin{array}{c}129.6^{* * * *} \\
(43.5)\end{array}$ \\
\hline
\end{tabular}

Note: All regressions are estimated using the Stata command "qreg2” by Machado and Santos Silva (2011). Standard errors are clustered by individual and are asymptotically robust to heteroskedasticity. All regressions include the standard list of covariates included in Table 2 as well as a set of region of residence, year and one-digit standard industrial classification dummy variables. * indicates significance level (p-value) below 0.10 , ** below 0.05 and *** below 0.01 . 
Figure 1: Estimated relationships between optimism and earnings

\section{Optimism and Earnings}
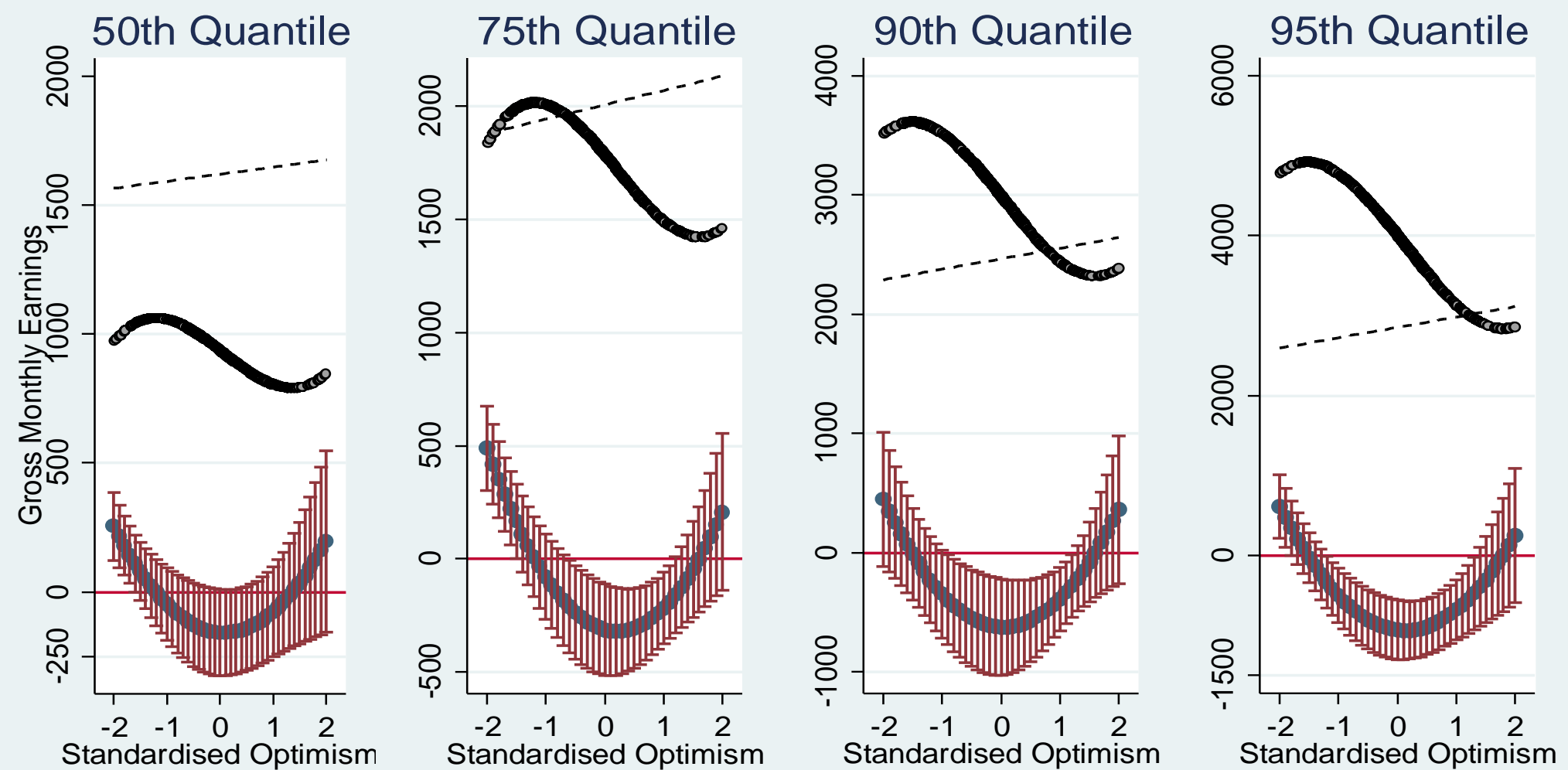

$$
\begin{array}{ll}
\ldots & \text { Ditted (Employed) } \\
& \text { Derivative of Self-Employed Earnings }
\end{array}
$$




\section{APPENDIX:}

Table A1: Descriptive statistics

\begin{tabular}{|c|c|c|c|c|c|}
\hline \multirow[b]{2}{*}{ Variable } & \multirow[b]{2}{*}{ Description } & \multicolumn{2}{|c|}{ Futures } & \multicolumn{2}{|c|}{ Nevers } \\
\hline & & Mean & Std. Dev. & Mean & Std. Dev. \\
\hline \multicolumn{6}{|l|}{$\begin{array}{l}\text { Financial forecasts and } \\
\text { realizations } \\
\text { Financial forecast }(t) \text { : }\end{array}$} \\
\hline Better off & Reference category & 0.415 & 0.493 & 0.385 & 0.487 \\
\hline Same & & 0.495 & 0.500 & 0.517 & 0.500 \\
\hline Worse off & & 0.091 & 0.287 & 0.098 & 0.297 \\
\hline $\begin{array}{l}3 \text { point scale (Dependent } \\
\text { Variable) }\end{array}$ & $\begin{array}{l}-1 \text { if individual } \\
\text { financial forecast } \\
\text { 'worse off', } 0 \text { if } \\
\text { 'same' and } 1 \text { if } \\
\text { 'better off' at } t\end{array}$ & 0.324 & 0.633 & 0.287 & 0.633 \\
\hline \multicolumn{6}{|l|}{ Financial realization $(t+1)$ : } \\
\hline Better off & Reference category & 0.381 & 0.486 & 0.380 & 0.485 \\
\hline Same & & 0.392 & 0.488 & 0.401 & 0.490 \\
\hline Worse off & & 0.226 & 0.418 & 0.220 & 0.414 \\
\hline $\begin{array}{l}3 \text { point scale (Dependent } \\
\text { Variable) }\end{array}$ & $\begin{array}{l}-1 \text { if individual } \\
\text { realised 'worse off', } \\
0 \text { if 'same' and } 1 \text { if } \\
\text { 'better off' at } t+1\end{array}$ & 0.155 & 0.764 & 0.160 & 0.757 \\
\hline \multicolumn{6}{|l|}{ Financial realization $(t)$ : } \\
\hline Better off & Reference category & 0.407 & 0.491 & 0.401 & 0.490 \\
\hline Same & & 0.366 & 0.482 & 0.380 & 0.485 \\
\hline Worse off & & 0.227 & 0.419 & 0.219 & 0.414 \\
\hline 3 point scale & $\begin{array}{l}-1 \text { if individual } \\
\text { realised 'worse off', } \\
0 \text { if 'same' and } 1 \text { if } \\
\text { 'better off' at } t\end{array}$ & 0.181 & 0.775 & 0.182 & 0.766 \\
\hline \multicolumn{6}{|l|}{ Forecast error: } \\
\hline $\begin{array}{l}5 \text { point scale (Dependent } \\
\text { Variable) }\end{array}$ & $\begin{array}{l}\text { Range from }-2 \text { to }+2 \\
\text { (Forecast } t \text { minus } \\
\text { Realization } t+1 \text { ) }\end{array}$ & 0.169 & 0.871 & 0.127 & 0.849 \\
\hline \multicolumn{6}{|l|}{ Demographics: } \\
\hline Age & Years & 35.52 & 10.02 & 34.84 & 10.53 \\
\hline Age $^{2}$ & & 1361.79 & 739.16 & 1324.42 & 767.72 \\
\hline Male & & 0.634 & 0.482 & 0.492 & 0.500 \\
\hline \multicolumn{6}{|l|}{$\begin{array}{l}\text { Marital Status and } \\
\text { Household Composition: }\end{array}$} \\
\hline $\begin{array}{l}\text { Single, never married } \\
\text { Widowed/divorced/ }\end{array}$ & Reference category & 0.206 & 0.405 & 0.229 & 0.420 \\
\hline separated & & 0.055 & 0.228 & 0.063 & 0.243 \\
\hline Married/cohabiting partner & & 0.607 & 0.488 & 0.611 & 0.488 \\
\hline
\end{tabular}


employed

Married/cohabiting partner

not employed

$\begin{array}{llll}0.131 & 0.338 & 0.097 & 0.297\end{array}$

Number of dependent

children in household

$\begin{array}{llll}0.707 & 0.983 & 0.708 & 0.968\end{array}$

Educational Attainment:

University/college degree

Vocational college

qualification

$\begin{array}{llll}0.175 & 0.380 & 0.157 & 0.364\end{array}$

A-level

$\begin{array}{llll}0.088 & 0.283 & 0.076 & 0.265\end{array}$

O-levels/GCSEs

0.268

0.443

$0.210 \quad 0.408$

No qualifications

0.315

0.465

$0.382 \quad 0.486$

Housing Tenure:

Reference category

0.154

0.175

0.380

Outright owner

$\begin{array}{lllll} & 0.100 & 0.300 & 0.102 & 0.303 \\ & 0.736 & 0.441 & 0.695 & 0.460 \\ \text { Reference category } & 0.089 & 0.285 & 0.092 & 0.289 \\ & 0.075 & 0.263 & 0.111 & 0.314\end{array}$

Private sector rental

Social sector rental

Source: authors’ tabulations from BHPS 1991-2008 
Table A2: Fixed effect optimism equations

\begin{tabular}{|c|c|c|c|c|}
\hline & \multicolumn{2}{|c|}{ (1) Futures } & \multicolumn{2}{|c|}{ (2) Nevers } \\
\hline Dependent Variable & \multicolumn{2}{|c|}{ Forecast Error } & \multicolumn{2}{|c|}{ Forecast Error } \\
\hline Variable & Coefficients & $\begin{array}{c}\text { Robust } \\
\text { Standard } \\
\text { Errors }\end{array}$ & Coefficients & $\begin{array}{c}\text { Robust } \\
\text { Standard Errors }\end{array}$ \\
\hline \multicolumn{5}{|l|}{ Demographics } \\
\hline Age & -0.002 & 0.079 & -0.026 & 0.028 \\
\hline $\mathrm{Age}^{2 / 100}$ & 0.041 & 0.036 & -0.020 & 0.016 \\
\hline \multicolumn{5}{|c|}{ Marital Status and Household Composition (Reference: Single, never married) } \\
\hline Widowed/divorced/separated & -0.145 & 0.149 & -0.052 & 0.059 \\
\hline $\begin{array}{l}\text { Married/cohabiting-partner } \\
\text { employed }\end{array}$ & 0.023 & 0.107 & -0.002 & 0.036 \\
\hline $\begin{array}{l}\text { Married/cohabiting-partner } \\
\text { not employed }\end{array}$ & -0.100 & 0.128 & 0.001 & 0.044 \\
\hline $\begin{array}{l}\text { Number of dependent } \\
\text { children in household }\end{array}$ & 0.009 & 0.037 & $0.042 * * *$ & 0.015 \\
\hline \multicolumn{5}{|c|}{ Educational Attainment (Reference: No qualifications) } \\
\hline University/college degree & -0.391 & 0.365 & 0.130 & 0.153 \\
\hline $\begin{array}{l}\text { Vocational college } \\
\text { qualification }\end{array}$ & -0.570 & 0.357 & 0.024 & 0.145 \\
\hline A-level & $-0.843 * * *$ & 0.302 & -0.003 & 0.111 \\
\hline O-levels/GCSEs & $-0.734 * *$ & 0.324 & 0.054 & 0.114 \\
\hline \multicolumn{5}{|c|}{ Housing Tenure (Reference: Social sector rental) } \\
\hline Outright owner & -0.186 & 0.183 & 0.085 & 0.056 \\
\hline Own with mortgage & -0.150 & 0.155 & $0.117 * * *$ & 0.044 \\
\hline Private sector rental & -0.127 & 0.168 & $0.124^{* *}$ & 0.050 \\
\hline \multicolumn{5}{|c|}{ Financial Realizations time $t$ (reference category: 'worse') } \\
\hline 'Better' & -0.024 & 0.053 & $0.159 * * *$ & 0.017 \\
\hline 'Same’ & $-0.103 *$ & 0.055 & 0.013 & 0.017 \\
\hline Region dummies included & Yes & & Yes & \\
\hline Year dummies included & Yes & & Yes & \\
\hline \multirow[t]{2}{*}{ Observations } & \multicolumn{2}{|c|}{3138} & \multicolumn{2}{|c|}{28830} \\
\hline & \multicolumn{2}{|c|}{ (618 Individuals) } & \multicolumn{2}{|c|}{ (7367 Individuals) } \\
\hline F Test & \multicolumn{2}{|c|}{$1.69 * * *$} & \multicolumn{2}{|c|}{$7.13^{* * *}$} \\
\hline
\end{tabular}

Notes: All regressions are clustered by individual and include year and region of residence dummy variables (coefficients not reported). * indicates significance level (p-value) below 0.10 , ** below 0.05 and $* * *$ below 0.01 . 
Table A3: Fixed effect log hourly real wage equations

\begin{tabular}{|c|c|c|c|c|}
\hline & \multicolumn{2}{|c|}{ (1) Futures } & \multicolumn{2}{|c|}{ (2) Nevers } \\
\hline Dependent Variable & \multicolumn{2}{|c|}{ Log Hourly Real Wage } & \multicolumn{2}{|c|}{ Log Hourly Real Wage } \\
\hline Variable & Coefficients & $\begin{array}{c}\text { Robust } \\
\text { Standard } \\
\text { Errors } \\
\end{array}$ & Coefficients & $\begin{array}{c}\text { Robust } \\
\text { Standard } \\
\text { Errors } \\
\end{array}$ \\
\hline \multicolumn{5}{|l|}{ Demographics } \\
\hline Age & 0.031 & 0.024 & $0.076 * * *$ & 0.008 \\
\hline $\mathrm{Age}^{2} / 100$ & $-0.093 * * *$ & 0.016 & $-0.104^{* * *}$ & 0.005 \\
\hline \multicolumn{5}{|c|}{ Marital Status and Household Composition (Reference: Single, never married) } \\
\hline Widowed/divorced/separated & $0.136 * *$ & 0.069 & $0.031^{*}$ & 0.017 \\
\hline $\begin{array}{l}\text { Married/cohabiting-partner } \\
\text { employed }\end{array}$ & $0.109 * *$ & 0.049 & $0.048 * * *$ & 0.011 \\
\hline $\begin{array}{l}\text { Married/cohabiting-partner } \\
\text { not employed }\end{array}$ & $0.100 *$ & 0.054 & $0.064 * * *$ & 0.013 \\
\hline Number of dependent & & & & \\
\hline \multicolumn{3}{|c|}{ Health (Reference: Health-other) } & $-0.021 * * *$ & 0.005 \\
\hline Health-excellent & 0.004 & 0.024 & 0.000 & 0.007 \\
\hline Health-good & 0.005 & 0.018 & 0.002 & 0.005 \\
\hline \multicolumn{5}{|c|}{ Educational Attainment (Reference: No qualifications) } \\
\hline $\begin{array}{l}\text { University/college degree } \\
\text { Vocational college }\end{array}$ & 0.063 & 0.126 & $0.177 * * *$ & 0.054 \\
\hline qualification & 0.157 & 0.127 & $0.091 *$ & 0.050 \\
\hline A-level & 0.094 & 0.133 & 0.065 & 0.043 \\
\hline O-levels/GCSEs & -0.041 & 0.106 & -0.006 & 0.040 \\
\hline \multicolumn{5}{|l|}{ Labour Market Characteristics } \\
\hline Union covered, member & $0.082 * *$ & 0.032 & $0.064 * * *$ & 0.011 \\
\hline Union covered, non member & 0.035 & 0.028 & 0.013 & 0.009 \\
\hline Holding a second job & $-0.053^{*}$ & 0.031 & $-0.018 * *$ & 0.009 \\
\hline Job tenure & 0.001 & 0.004 & 0.000 & 0.001 \\
\hline Job tenure $2 / 100$ & 0.008 & 0.017 & 0.004 & 0.005 \\
\hline Manager / supervisor & $0.035 *$ & 0.021 & $0.042 * * *$ & 0.006 \\
\hline $\begin{array}{l}\text { Promotion opportunities } \\
\text { available }\end{array}$ & -0.025 & 0.019 & 0.007 & 0.005 \\
\hline $\begin{array}{l}\text { Pay includes bonus / profit } \\
\text { share }\end{array}$ & 0.021 & 0.021 & $0.033 * * *$ & 0.005 \\
\hline $\begin{array}{l}\text { Employer provided pension } \\
\text { available }\end{array}$ & $0.079 * * *$ & 0.030 & $0.070 * * *$ & 0.008 \\
\hline Pay includes annual rises & -0.019 & 0.016 & $0.018 * * *$ & 0.005 \\
\hline Shift worker & 0.058 & 0.043 & 0.014 & 0.010 \\
\hline \multicolumn{5}{|l|}{ Seasonal/Agency } \\
\hline Temping/Casual contract & 0.029 & 0.056 & -0.026 & 0.018 \\
\hline Fixed-term contact & -0.020 & 0.062 & -0.008 & 0.016 \\
\hline \multicolumn{5}{|c|}{ Flexibility in job location (Reference: work at employers' premises) } \\
\hline Work from home & 0.168 & 0.183 & $0.120 * *$ & 0.046 \\
\hline Other work location & $0.063^{*}$ & 0.033 & 0.005 & 0.010 \\
\hline Work needs travelling & 0.036 & 0.030 & $0.022 *$ & 0.011 \\
\hline
\end{tabular}




\begin{tabular}{|c|c|c|c|c|}
\hline Managers \& Administrators & $0.158 * * *$ & 0.052 & $0.111^{* * *}$ & 0.017 \\
\hline Professional & $0.185^{* * *}$ & 0.060 & $0.129 * * *$ & 0.019 \\
\hline \multicolumn{5}{|l|}{ Associate Professional \& } \\
\hline Technical & $0.097 *$ & 0.056 & $0.092 * * *$ & 0.018 \\
\hline Clerical \& Secretarial & $0.145 * *$ & 0.063 & $0.041 * *$ & 0.017 \\
\hline Craft \& Related & 0.067 & 0.052 & $0.043 * *$ & 0.018 \\
\hline Personal \& Protective Service & 0.011 & 0.075 & -0.018 & 0.018 \\
\hline Sales & 0.022 & 0.067 & -0.004 & 0.019 \\
\hline Plant \& Machine Operatives & 0.063 & 0.049 & $0.034 *$ & 0.018 \\
\hline \multicolumn{5}{|c|}{ Employing Sector (Reference: Private Firm) } \\
\hline Civil Service & -0.017 & 0.052 & -0.011 & 0.021 \\
\hline Local Government & 0.005 & 0.066 & $0.031^{*}$ & 0.018 \\
\hline Other Public & -0.035 & 0.062 & -0.005 & 0.016 \\
\hline Non-Profit & 0.002 & 0.128 & -0.004 & 0.023 \\
\hline \multicolumn{5}{|c|}{ One-digit level industry (Reference: Agriculture \& Fishing) } \\
\hline Mining \& Quarrying & 0.141 & 0.120 & $0.134 * *$ & 0.053 \\
\hline Manufacturing & 0.142 & 0.101 & 0.046 & 0.033 \\
\hline Electricity, Gas \& Water & 0.059 & 0.145 & $0.093^{*}$ & 0.049 \\
\hline Construction & 0.174 & 0.123 & 0.026 & 0.035 \\
\hline Wholesale \& Retail Trade & 0.035 & 0.097 & -0.024 & 0.033 \\
\hline Hotels \& Restaurants & -0.021 & 0.121 & $-0.076^{* *}$ & 0.035 \\
\hline \multicolumn{5}{|l|}{ Transport, Storage \& } \\
\hline Communication & 0.020 & 0.106 & 0.011 & 0.035 \\
\hline Financial Intermediation & 0.089 & 0.111 & 0.044 & 0.037 \\
\hline \multicolumn{5}{|l|}{ Real Estate \& Business } \\
\hline Activities & 0.117 & 0.108 & 0.042 & 0.032 \\
\hline \multicolumn{5}{|l|}{ Public Administration \& } \\
\hline Defence & $0.323 * * *$ & 0.119 & 0.037 & 0.033 \\
\hline Education & 0.161 & 0.109 & 0.022 & 0.038 \\
\hline Health \& Social Work & 0.036 & 0.132 & -0.031 & 0.034 \\
\hline Social \& Personal Services & -0.018 & 0.111 & -0.013 & 0.035 \\
\hline \multicolumn{5}{|l|}{ Private Households \& Extra- } \\
\hline Territorial Organizations & 0.151 & 0.100 & 0.044 & 0.041 \\
\hline \multicolumn{5}{|c|}{ Firm Size -Number of Co-workers (Reference: Over 500) } \\
\hline $1-9$ & -0.042 & 0.035 & $-0.073 * * *$ & 0.011 \\
\hline $10-24$ & 0.019 & 0.038 & $-0.054 * * *$ & 0.010 \\
\hline $25-49$ & 0.034 & 0.042 & $-0.046 * * *$ & 0.010 \\
\hline $50-99$ & 0.034 & 0.037 & $-0.027 * * *$ & 0.010 \\
\hline 100-199 & 0.005 & 0.034 & $-0.018 *$ & 0.009 \\
\hline 200-499 & 0.015 & 0.027 & -0.007 & 0.008 \\
\hline Region dummies included & Yes & & Yes & \\
\hline Year dummies included & Yes & & Yes & \\
\hline \multirow[t]{2}{*}{ Observations } & \multicolumn{2}{|c|}{3321} & \multicolumn{2}{|c|}{33070} \\
\hline & \multicolumn{2}{|c|}{ (708 Individuals) } & \multicolumn{2}{|c|}{ (9010 Individuals) } \\
\hline F Test & \multicolumn{2}{|c|}{$11.33 * * *$} & \multicolumn{2}{|c|}{$44.90 * * *$} \\
\hline
\end{tabular}

Note: All regressions are clustered by individual and include year and region of residence dummy variables (coefficients not reported). * indicates significance level (p-value) below 0.10 , ** below 0.05 and $* * *$ below 0.01 
Table A4: Fixed effect realization $t+1$ equations

\begin{tabular}{|c|c|c|c|c|}
\hline & \multicolumn{2}{|c|}{ (1) Futures } & \multicolumn{2}{|c|}{ (2) Nevers } \\
\hline Dependent Variable & \multicolumn{2}{|c|}{ Realization $t+1$} & \multicolumn{2}{|c|}{ Realization $t+1$} \\
\hline Variable & Coefficients & $\begin{array}{c}\text { Robust } \\
\text { Standard } \\
\text { Errors } \\
\end{array}$ & Coefficients & $\begin{array}{c}\text { Robust } \\
\text { Standard } \\
\text { Errors }\end{array}$ \\
\hline \multicolumn{5}{|l|}{ Demographics } \\
\hline Age & -0.050 & 0.060 & -0.004 & 0.024 \\
\hline $\mathrm{Age}^{2} / 100$ & 0.041 & 0.000 & $0.063 * * *$ & 0.014 \\
\hline \multicolumn{5}{|c|}{ Marital Status and Household Composition (Reference: Single, never married) } \\
\hline Widowed/divorced/separated & 0.059 & 0.134 & 0.060 & 0.051 \\
\hline $\begin{array}{l}\text { Married/cohabiting-partner } \\
\text { employed }\end{array}$ & -0.029 & 0.097 & 0.017 & 0.032 \\
\hline $\begin{array}{l}\text { Married/cohabiting-partner not } \\
\text { employed }\end{array}$ & 0.099 & 0.112 & 0.052 & 0.039 \\
\hline $\begin{array}{l}\text { Number of dependent children in } \\
\text { household }\end{array}$ & 0.042 & 0.031 & 0.004 & 0.013 \\
\hline \multicolumn{5}{|c|}{ Educational Attainment (Reference: No qualifications) } \\
\hline University/college degree & 0.292 & 0.310 & 0.001 & 0.133 \\
\hline Vocational college qualification & 0.441 & 0.318 & 0.019 & 0.121 \\
\hline A-level & $0.722 * * *$ & 0.258 & -0.005 & 0.104 \\
\hline O-levels/GCSEs & $0.522 *$ & 0.284 & 0.006 & 0.107 \\
\hline \multicolumn{5}{|c|}{ Housing Tenure (Reference: Social sector rental) } \\
\hline Outright owner & $0.268^{*}$ & 0.152 & $-0.174 * * *$ & 0.048 \\
\hline Own with mortgage & $0.223 *$ & 0.122 & $-0.123 * * *$ & 0.038 \\
\hline Private sector rental & 0.124 & 0.124 & $-0.078 *$ & 0.043 \\
\hline \multicolumn{5}{|c|}{ Financial Realizations time $t$ (reference category: 'worse') } \\
\hline 'Better' & -0.013 & 0.045 & $-0.132 * * *$ & 0.014 \\
\hline ‘Same’ & 0.007 & 0.045 & $-0.075 * * *$ & 0.014 \\
\hline Region dummies included & Yes & & Yes & \\
\hline Year dummies included & Yes & & Yes & \\
\hline Observations & $\begin{array}{r}31 \\
\text { (618 Ind }\end{array}$ & duals) & $\begin{array}{r}28 \\
\text { (7367 Inc }\end{array}$ & $\begin{array}{l}0 \\
\text { iduals) }\end{array}$ \\
\hline F Test & 11.0 & & 6.16 & \\
\hline
\end{tabular}

Notes: All regressions are clustered by individual and include year and region of residence dummy variables (coefficients not reported). * indicates significance level ( $\mathrm{p}$-value) below 0.10 , ** below 0.05 and $* * *$ below 0.01 . 
Table A5a: Quantile regression for gross monthly self-employed earnings

\begin{tabular}{|c|c|c|c|c|c|c|c|c|c|c|}
\hline \multicolumn{11}{|l|}{ Dependent } \\
\hline \multirow{2}{*}{$\begin{array}{l}\text { Variable } \\
\text { Quantile } \\
\end{array}$} & \multicolumn{2}{|c|}{$25^{\text {th }}$} & \multicolumn{2}{|c|}{$50^{\text {th }}$} & \multicolumn{2}{|c|}{$75^{\text {th }}$} & \multicolumn{2}{|c|}{$90^{\text {th }}$} & \multicolumn{2}{|c|}{$95^{\text {th }}$} \\
\hline & & Robust & & Robust & & Robust & & Robust & & Robust \\
\hline Variable & Coef. & S.E's & Coef. & S.E's & Coef. & S.E's & Coef. & S.E's & Coef. & S.E's \\
\hline Optimism & 17.108 & 66.098 & $-157.664 *$ & 85.314 & $-312.906 * * *$ & 102.446 & $-624.416 * * *$ & 206.413 & $-932.845 * * *$ & 189.083 \\
\hline Optimism $^{2}$ & -10.287 & 18.044 & -7.432 & 22.688 & -35.215 & 23.932 & -11.108 & 45.878 & -45.836 & 51.498 \\
\hline Optimism ${ }^{3}$ & 0.483 & 8.820 & $31.890 * * *$ & 11.439 & $55.128 * * *$ & 13.701 & $85.852 * * *$ & 32.143 & $113.437 * * *$ & 28.345 \\
\hline \multicolumn{11}{|c|}{ Whether Draws up Profit/Loss Accounts (Reference: Does not draw up accounts) } \\
\hline Draws up accounts & -87.088 & 63.173 & -121.734 & 98.702 & -153.885 & 131.408 & 90.164 & 271.944 & 157.357 & 197.058 \\
\hline Not yet but will be & $200.946 * *$ & 81.787 & $280.394 * *$ & 118.723 & 301.063 & 196.279 & 531.459 & 396.377 & 421.091 & 430.695 \\
\hline \multicolumn{11}{|c|}{ FE Paid-Employment Performance Controls } \\
\hline Pastearnings & 14.457 & 76.510 & $196.449 * *$ & 89.858 & $552.457 * * *$ & 139.633 & $1112.131^{* * *}$ & 259.818 & $1315.997 * * *$ & 299.575 \\
\hline Pastrealizations & 10.600 & 72.407 & 35.989 & 84.087 & 104.002 & 104.927 & 94.301 & 176.844 & -13.174 & 280.327 \\
\hline \multicolumn{11}{|c|}{ Health (Reference: Health-other) } \\
\hline Health-excellent & 5.869 & 77.471 & 59.016 & 77.447 & -0.050 & 107.120 & -20.674 & 228.662 & -84.559 & 281.246 \\
\hline Health-good & 53.421 & 57.224 & 17.659 & 68.291 & 36.104 & 89.710 & 200.249 & 184.199 & 217.613 & 230.933 \\
\hline \multicolumn{11}{|l|}{ Demographics } \\
\hline Age & -0.777 & 20.413 & 15.688 & 26.923 & 64.872 & 43.672 & $187.537 * *$ & 77.239 & $203.104^{* *}$ & 88.472 \\
\hline Age $^{2}$ & -0.063 & 0.240 & -0.489 & 0.336 & $-1.357^{* *}$ & 0.531 & $-3.286^{* * *}$ & 0.993 & $-3.710 * * *$ & 1.071 \\
\hline Male & $129.697 * *$ & 61.975 & $224.774 * *$ & 97.735 & $367.045 * * *$ & 117.781 & $483.088 *$ & 268.576 & $810.362 * * *$ & 217.503 \\
\hline \multicolumn{11}{|c|}{$\begin{array}{l}\text { Marital Status and Household Composition (Reference: Single, never married) } \\
\text { Widowed/divorced }\end{array}$} \\
\hline /separated & -44.334 & 131.121 & -110.470 & 160.501 & $-434.870^{*}$ & 251.053 & $-1065.953 *$ & 607.408 & $-1484.861^{* *}$ & 585.634 \\
\hline Married/cohabiting & & & & & & & & & & \\
\hline $\begin{array}{l}\text {-partner employed } \\
\text { Married/cohabiting } \\
\text {-partner not }\end{array}$ & -118.796 & 85.379 & 24.892 & 141.725 & -290.916 & 228.637 & -177.744 & 639.459 & -613.487 & 549.696 \\
\hline employed & -60.550 & 111.735 & 150.903 & 160.206 & -71.625 & 254.241 & 501.086 & 826.337 & 26.183 & 701.986 \\
\hline Number of & 0.037 & 29.992 & -40.772 & 40.863 & -64.643 & 50.531 & $-249.129 * *$ & 114.289 & -232.469 & 160.088 \\
\hline
\end{tabular}


dependent children

in household

\section{Educational Attainmen}

HND/HNC

$\begin{array}{ll}-92.491 & 101.393\end{array}$

$-72.990$

110.502

$81.862 \quad 161.724$

245.142

$-27.647$

239.636

288.311

900.873

$973.143^{*}$

655.111

$1167.829 *$

$1275.453^{* *}$

648.943

A-level

$\begin{array}{lll}-114.892 & 87.803 & 10.096\end{array}$

$-128.214 \quad 107.718$

O-levels/GCSEs

112.658

$-141.719$

194.589

329.287

530.374

296.964

346.044

641.730

Housing Tenure (Reference: Social sector rental)

Outright owner

$\begin{array}{lll}-8.712 & 108.759 & 53.531\end{array}$

120.779

Own with

mortgage

$58.112 \quad 94.585 \quad 66.653$

103.877

$471.425^{* *} \quad 190.698$

(391.807

302.997

$591.680 *$

Private sector

rental

$\begin{array}{llll}-121.721 & 124.093 & -161.816 & 186.740\end{array}$

$444.697 * * * \quad 134.014$

510.599

$1488.626^{* * *}$

448.763

Parental background (Reference: Neither Parent Self-Employed)

Both parents self-

employed

$\begin{array}{lll}-134.909 & 97.994 & -230.251\end{array}$

304.746

198.382

392.714

331.786

472.711*

241.495

Father self-

employed

Mother self-

employed

$\begin{array}{llll}94.688 & 81.026 & 85.294 & 113.417\end{array}$

200.238

105.313

376.181

42.180

382.405

Labour Market Characteristics:

Job tenure

Job tenure ${ }^{2}$

$62.410^{* * *}$

Usual hours

$-2.295 * * *$

$161.801-195.914$

173.858

184.346

160.728

$-765.779$

491.811

$-700.522 *$

416.022

worked per week

Usual hours

worked per week ${ }^{2}$

Holds a second job

$$
7.227^{*}
$$

12.199

$81.464 * * *$

14.452

$-667.111^{* * *}$

142.714

10.409

291.690

146.319

355.009

One-digit industry

$-0.067 *$

0.499

$-2.578 * * *$

0.532

$128.813^{* * *}$

20.632

$-1184.706^{* * *}$

319.948

$-1556.145^{* * *}$

337.350

dummies

70.796

4.012

$25.336 * * *$

5.725

127.816***

48.734

89.774**

43.411

$40.211^{* * *}$

8.122

$40.822 * * *$

11.599

$-4.484 * * *$

1.421

0.040

$-0.242 * * * \quad 0.057$

$-0.384^{* * *}$

0.075

$-0.356 * * *$

0.105

$34.843^{* *}$

13.604

Region dummies

Yes

Yes

Yes

Yes

Yes

Yes

Yes

Yes
Yes
Yes

$-0.294^{* *}$

208.114

$-300.005$

272.338

Yes
Yes
Yes

Yes


F test of optimism

linearity 9

Pseudo R ${ }^{2}$

N
$0.24 \quad 6.82 * * *$

0.044
0.095
$19.14^{* * *}$
0.111

1964

(559 Individuals)
$4.00 * *$

0.112

$16.93^{* * *}$

0.097

Note: All regressions are estimated using the stata command “qreg2” by Machado and Santos Silva (2011). Standard errors are clustered by individual and are asymptotically robust to heteroskedasticity. All regressions include year, region of residence and one-digit standard industrial classification dummy variables (coefficients not reported). * indicates significance level (p-value) below 0.10 , ** below 0.05 and $* * *$ below 0.01. ๆ Test of coefficients for optimism ${ }^{2}$ and optimism ${ }^{3}$ jointly $=0$. 
Table A5b: Quantile regression for gross monthly employee earnings

\begin{tabular}{|c|c|c|c|c|c|c|c|c|c|c|}
\hline \multicolumn{11}{|l|}{ Dependent } \\
\hline \multirow[t]{2}{*}{ Quantile } & \multicolumn{2}{|c|}{$25^{\text {th }}$} & \multicolumn{2}{|l|}{$50^{\text {th }}$} & \multicolumn{2}{|c|}{$75^{\text {th }}$} & \multicolumn{2}{|c|}{$90^{\text {th }}$} & \multicolumn{2}{|c|}{$95^{\text {th }}$} \\
\hline & & Robust & & Robust & & Robust & & Robust & & Robust \\
\hline Variable & Coef. & S.E’s & Coef. & S.E’s & Coef. & S.E's & Coef. & S.E's & Coef. & S.E’'s \\
\hline Optimism & $29.788 * *$ & 11.688 & $27.404^{* *}$ & 13.011 & $63.470 * * *$ & 20.203 & $87.910 * *$ & 35.799 & $129.642^{* * *}$ & 43.496 \\
\hline Optimism ${ }^{2}$ & - & - & - & - & - & - & - & - & - & - \\
\hline Optimism ${ }^{3}$ & - & - & - & - & - & - & - & - & - & - \\
\hline \multicolumn{11}{|c|}{ Whether Draws up Profit/Loss Accounts (Reference: no accounts) } \\
\hline Draws up accounts & - & - & - & - & - & - & - & - & - & - \\
\hline Not yet but will be & - & - & - & - & - & - & - & - & - & - \\
\hline \multicolumn{11}{|c|}{ Financial Expectations Paid-Employment Performance Controls } \\
\hline Pastearnings & $959.101 * * *$ & 28.783 & $1198.286^{* * *}$ & 29.735 & $1421.931 * * *$ & 46.302 & $1592.305 * * *$ & 65.221 & $1752.905 * * *$ & 86.143 \\
\hline Pastrealizations & $74.010 * * *$ & 14.936 & $89.730 * * *$ & 18.115 & $174.447^{* * *}$ & 27.778 & $240.531 * * *$ & 41.678 & $324.475 * * *$ & 57.821 \\
\hline \multicolumn{11}{|c|}{ Health (Reference: Health-other) } \\
\hline Health-excellent & $38.453^{* * *}$ & 12.395 & $42.019 * * *$ & 14.924 & $46.160 * *$ & 20.594 & $76.295 * *$ & 32.447 & $171.119 * * *$ & 66.287 \\
\hline Health-good & 12.294 & 9.166 & 13.497 & 10.875 & 21.656 & 15.821 & 25.922 & 23.234 & 31.870 & 33.814 \\
\hline \multicolumn{11}{|l|}{ Demographics } \\
\hline Age & $77.042 * * *$ & 3.815 & $94.668 * * *$ & 4.905 & $112.261 * * *$ & 6.415 & $128.506^{* * *}$ & 10.692 & $127.813^{* * *}$ & 14.676 \\
\hline Age $^{2}$ & $-0.960 * * *$ & 0.047 & $-1.166^{* * *}$ & 0.059 & $-1.352 * * *$ & 0.078 & $-1.513 * * *$ & 0.133 & $-1.475 * * *$ & 0.184 \\
\hline Male & $97.216^{* * *}$ & 13.308 & $159.145^{* * *}$ & 16.622 & $193.710 * * *$ & 25.226 & $202.599 * * *$ & 35.661 & $236.889 * * *$ & 56.017 \\
\hline \multirow{2}{*}{\multicolumn{11}{|c|}{$\begin{array}{l}\text { Marital Status and Household Composition (Reference: Single, never married) } \\
\text { Widowed/divorced/ }\end{array}$}} \\
\hline & & & & & & & & & & \\
\hline separated & $55.403 * * *$ & 19.317 & 42.159 & 27.317 & 30.718 & 38.632 & 40.775 & 60.991 & 64.361 & 81.792 \\
\hline $\begin{array}{l}\text { Married/cohabiting } \\
\text {-partner employed }\end{array}$ & $74.363 * * *$ & 15.510 & $83.447 * * *$ & 21.698 & 49.241 & 30.520 & -16.116 & 43.927 & -23.550 & 68.646 \\
\hline $\begin{array}{l}\text { Married/cohabiting } \\
\text {-partner not }\end{array}$ & & & & & & & & & & \\
\hline employed & $106.645^{* * *}$ & 20.792 & $117.719 * * *$ & 27.955 & $146.376^{* * *}$ & 42.235 & $193.972 * *$ & 78.393 & $243.125 * *$ & 113.374 \\
\hline No. of dependent & $-28.893 * * *$ & 7.567 & $-31.319 * * *$ & 8.796 & -9.830 & 11.404 & 3.779 & 19.917 & 16.830 & 28.004 \\
\hline
\end{tabular}


children in

household

\section{Educational Attainment}

HND/HNC

$505.498 * * * \quad 25.783$

$647.004 * * *$

31.778

$784.456 * * *$

48.089

$955.217^{* * *}$ $322.821^{* * *}$

48.920

A-level

$241.417 * * * \quad 27.963$

$293.457 * * * \quad 33.486$

$\begin{array}{llll}104.598 * * * & 16.075 & 101.434 * * * & 20.307\end{array}$

83.171***

31.845

O-levels/GCSEs

0.364

13.551

$-5.743$

17.156

$-59.197 * *$

26.804

$388.949 * * *$

76.691

74.438

$1103.901 * * * \quad 110.411$

Housing Tenure (Reference: Social sector rental)

Outright owner

$\begin{array}{lll}0.525 & 18.647 \quad-33.981\end{array}$

21.625

$-14.017$

31.573

$-67.838 *$

36.450

$132.704^{* *}$

64.169

Own with

$\begin{array}{llll}36.979 * * & 15.683 & 10.064 & 18.927\end{array}$

10.827

27.784

51.858

46.277

$-46.732$

47.073

Private sector

$\begin{array}{lllll}-29.619 & 22.790 & -46.563 * & 26.622 & -30.869\end{array}$

40.427

10.800

37.814

84.166

rental

(Reference: Neither Parent Self-Employed)

Both parents self-

employed

Father self-

employed

4.170

79.729

151.854

204.385

$160.001^{*}$

Mother self-

$\begin{array}{llll}-12.729 & 17.994 & -0.282 & 21.791\end{array}$

21.950

33.061

55.602

60.251

63.370

64.778

employed

2.049

42.534

16.076

42.187

$-18.665$

58.233

$-92.072$

86.041

61.898

290.733

Job tenure

Job tenure ${ }^{2}$

$4.158 * * *$

1.568

$-2.074$

1.784

$-6.343 * *$

3.029

$-14.353 * * *$

4.590

$-23.802 * * *$

8.451

0.105

0.222

0.166

0.521

0.374

worked per week

$56.414 * * * \quad 2.931$

$42.324 * * * \quad 3.032$

$23.031 * * *$

7.042

1.282

5.030

$-26.075^{* * *}$

6.077

worked per week ${ }^{2}$

$-0.356 * * * \quad 0.042$

$-0.145 * * *$

0.049

0.153

0.126

$0.509 * * *$

0.088

$0.984 * * *$

$-120.485^{* *}$

0.096

$-76.580 * * * \quad 24.392$

$-100.220 * *$

40.103

Yes

Yes

Yes

Yes
Yes

Yes

Yes

Yes

Yes 
Note: All regressions are estimated using the stata command “qreg2” by Machado and Santos Silva (2011). Standard errors are clustered by individual and are asymptotically robust to heteroskedasticity. All regressions include year, region of residence and one-digit standard industrial classification dummy variables (coefficients not reported). * indicates significance level (p-value) below 0.10 , ** below 0.05 and $* * *$ below 0.01 . 
Table A6: Ordered probit regression for forecast error, expectations and realizations

\begin{tabular}{|c|c|c|c|c|c|c|}
\hline $\begin{array}{l}\text { Dependent Variable } \\
\end{array}$ & \multicolumn{2}{|c|}{ Forecast Error } & \multicolumn{2}{|c|}{ Expectation $t$} & \multicolumn{2}{|c|}{ Realization $t+1$} \\
\hline Variable & Coefficients & $\begin{array}{c}\text { Robust } \\
\text { Standard } \\
\text { Errors } \\
\end{array}$ & Coefficients & $\begin{array}{c}\text { Robust } \\
\text { Standard } \\
\text { Errors } \\
\end{array}$ & Coefficients & $\begin{array}{c}\text { Robust } \\
\text { Standard } \\
\text { Errors } \\
\end{array}$ \\
\hline Future Divorcee & $0.103^{* * *}$ & 0.033 & $0.158 * * *$ & 0.050 & 0.001 & 0.038 \\
\hline Year of divorce & 0.141 & 0.155 & -0.192 & 0.148 & $-0.341 * *$ & 0.166 \\
\hline Divorced & $0.087 * * *$ & 0.025 & $0.099 * * *$ & 0.037 & -0.026 & 0.027 \\
\hline Year of ReMarriage & -0.056 & 0.130 & $0.298 *$ & 0.157 & $0.325 * *$ & 0.156 \\
\hline Re-Married & 0.063 & 0.051 & 0.062 & 0.054 & -0.031 & 0.047 \\
\hline Smoker (Number of Cigarettes) & $0.005^{* * *}$ & 0.001 & $0.006 * * *$ & 0.001 & $-0.001 *$ & 0.001 \\
\hline \multicolumn{7}{|l|}{ Demographics } \\
\hline Age & -0.007 & 0.006 & $-0.042 * * *$ & 0.007 & $-0.028 * * *$ & 0.006 \\
\hline $\mathrm{Age}^{2 / 100}$ & 0.000 & 0.000 & $0.000 * * *$ & 0.000 & $0.000 * * *$ & 0.000 \\
\hline Male & $0.034 * *$ & 0.013 & $0.040 * *$ & 0.018 & -0.009 & 0.014 \\
\hline \multicolumn{7}{|l|}{ Employment Status (Reference: Employee) } \\
\hline Self-Employed & $0.126 * * *$ & 0.022 & $0.207 * * *$ & 0.031 & 0.012 & 0.023 \\
\hline \multicolumn{7}{|l|}{ Household Composition } \\
\hline Number of dependent children in household & $0.022 * * *$ & 0.007 & 0.011 & 0.009 & $-0.019 * * *$ & 0.007 \\
\hline \multicolumn{7}{|c|}{ Educational Attainment (Reference: No qualifications) } \\
\hline University/college degree & $-0.125 * * *$ & 0.023 & -0.040 & 0.032 & $0.120 * * *$ & 0.025 \\
\hline Vocational college qualification & -0.043 & 0.028 & 0.044 & 0.039 & $0.085 * * *$ & 0.030 \\
\hline A-level & -0.018 & 0.020 & -0.008 & 0.029 & 0.012 & 0.022 \\
\hline O-levels/GCSEs & 0.001 & 0.018 & 0.018 & 0.025 & 0.011 & 0.019 \\
\hline \multicolumn{7}{|c|}{ Housing Tenure (Reference: Social sector rental) } \\
\hline Outright owner & $-0.086 * * *$ & 0.029 & $-0.207 * * *$ & 0.038 & $-0.058 * *$ & 0.030 \\
\hline Own with mortgage & -0.035 & 0.025 & -0.052 & 0.032 & 0.001 & 0.026 \\
\hline Private sector rental & -0.015 & 0.037 & -0.018 & 0.048 & 0.004 & 0.039 \\
\hline \multicolumn{7}{|c|}{ Financial Realizations time $t$ (reference category: 'worse') } \\
\hline 'Better' & $-0.337 * * *$ & 0.017 & $0.464 * * *$ & 0.023 & $0.790 * * *$ & 0.020 \\
\hline 'Same' & $-0.301 * * *$ & 0.015 & -0.009 & 0.020 & $0.365 * * *$ & 0.017 \\
\hline
\end{tabular}




\begin{tabular}{lccc} 
Region dummies included & Yes & Yes & Yes \\
Year dummies included & Yes & Yes & Yes \\
\hline Observations & & -35064.03 & -41274.16 \\
\hline Log Likelihood & -48832.91 & $1937.49^{* * *}$ & $2823.81^{* * *}$ \\
chi $^{2}$ & $1099.35^{* * *}$ & 0.044 & 0.046 \\
Pseudo ${ }^{2}$ & 0.014 & Individuals) \\
\hline
\end{tabular}

Notes: All regressions are clustered by individual and include year and region of residence dummy variables (coefficients not reported). * indicates significance level (p-value) below 0.10 , ** below 0.05 and $* * *$ below 0.01 . 